\title{
Brock Education
}

A Journal of Educational Research and Practice

\section{Volume 12 (2) Fall 2003 \\ Faculty of Education Brock University}




\section{Human Adaptation and the Ingenuity Gap'}

\section{Thomas Homer-Dixon University of Toronto}

I have been working for many years on the problem of adaptation: how societies or organisms, species, or systems of various kinds adapt to complex and rapid change. In this paper, I will outline my theories and my thinking about adaptation as summarized in the book, The Ingenuity Gap. I will also highlight five aspects of education for the future: education for complexity and what that means; education for reconnection to the micro and macro scales around us; education that increases our respect for experiential knowledge; education that will encourage a recognition of our connectivity through time, from the present into the future; and finally, education to broaden our conception of values. I'll touch on each one of these points in my presentation today.

Let's start by going over the basic argument that I've been developing in books such as The Ingenuity Gap. I start by asking a number of core questions:

- Are we creating a world that's too complex to manage?

- Do the "experts" really know what's going on?

- Are we really as smart as we think we are?

- Then finally, the most important question, can we solve the problems of the future?

I'm interested in developing ideas and taking them to the general public, explaining or extracting some of the ideas and knowledge from isolated worlds of academe and then providing them for a general audience. One way I do that is to tell a lot of stories. So I will start my response to these four questions this evening by telling a story that comes at the beginning of the book. Now one of the mildly amusing things about this book is that when it first came out it was selling very well in airports across the country. I don't think people

Professor Homer-Dixon is Director of the Centre for the Study of Peace and Conflict at the University of Toronto, and the author of numerous books on the human and physical environment.

1. This is the transcribed, edited text of a lecture delivered by Dr. Homer-Dixon at Brock University on November 12, 2002 
realized when they bought the book and then settled into their comfortable seats on the airplane that the first thing they were going to read about was a horrific airplane crash. But I'm going to describe that incident today because it will motivate my subsequent comments in this presentation.

The incident occurred on July 19, 1989, during United Airlines Flight 232 between Denver and Chicago. About half-way through the flight, the rear tail engine on the DC-10 blew up. Now, there are three engines on the DC-10: a large one in the tail and one over each wing. When the rear tail engine blew up, the shrapnel from the explosion destroyed all three hydraulic systems in the plane. Those hydraulic systems were necessary for controlling the flight surfaces - the ailerons, the rudder, the flaps, and the slats that allowed the crew in the cockpit to direct the plane through the atmosphere. So all of a sudden, the pilot and the co-pilots sitting in their seats found that the wheels and columns in front of them were dead. They had no control over the direction of the plane.

Immediately the plane started turning into a rightward, downward dive, and about 15 seconds later, just at the moment that the plane would have been irretrievably lost, the captain tried something. He increased power to the right engine, and lo and behold, that brought the right engine up and stabilized the plane. At that point, he discovered that he could maintain some modest control over the airplane by increasing and decreasing power to the right and left engines - what they later called 'differential engine thrust' - and basically skidding the plane through the atmosphere like that. After the engine exploded, the plane described a series of rightward turns across the Iowa countryside, but that modest control enabled them to make one left-hand turn to line the plane up with the shortest runway at Sioux City, Iowa. At the last moment, just before they brought it down on the ground, they made one very tight rightward turn, dropped below radar cover, and then eventually brought the plane down.

There's quite a bit more to the story than that. Some of the details I'm giving you today are from a conversation with the captain, Al Haines, whom I spoke to when I was writing my book.

That period of time lasted forty-four minutes and the cockpit crew had some help. It turned out there was an extra pilot on board - somebody called a "check airman" - who was responsible for checking on the performance of United Airlines crews as they flew back and forth across the country. He happened to be off duty but he was sitting in first class and he thought something was wrong. The explosion had been in the back of the plane, so it had been fairly muffled, but he started to see the sun going from one side of the plane to the other, and he knew that wasn't right. So he thought that perhaps he should offer his help to the cockpit crew. He spoke to a flight attendant who 
went up and talked to the captain, and the captain immediately called the check airman into the cockpit and explained what was going on.

There was pandemonium in the cockpit. It was clear that the captain, the co-pilot, and the first officer sitting behind them had too many things to do. So when the check airman asked, "What can I do?" the captain said, "Could you take over control of the two engines?" So from that point on, the check airman stood between the pilot and the co-pilot with a hand on each of the engine throttles and watched the bank of gauges in front of him and steered the aircraft. Eventually, he was able to bring the plane down on the shortest runway in Sioux City, Iowa. When the plane hit the ground, its right wing dipped at the last moment and caught the ground so that it crash-landed The plane hit the ground five times hard, and broke into three sections. The cockpit broke off and rolled across the tarmac, compressed into a piece of metal about two meters high. The remainder of the fuselage broke into two pieces, both of which cartwheeled and exploded in flames. But despite all of that, of the 300 people on board, 200 were saved, and the entire cockpit crew survived. The rescue teams on the ground didn't even go and look at the cockpit for 35 minutes after the crash, because they saw it off in the distance and thought it was such a wrecked hunk of metal that nobody could be alive inside, but when they went over and looked at the cockpit, they found that all the cockpit crew was still alive.

Now this is a pretty dramatic incident, and I'd probably claim that I started the book with this story because I wanted to make sure that nobody would put down the book once they started to read it. But there was more to it than that. I wanted to draw some lessons, highlight some aspects of our world illustrated by this story that I thought were important. So I will identify four points of resonance or connections between this particular incident and the state of our world today.

The first is the problem of cognitive overload. When I first heard about this incident in 1989, I filed it away and forgot about it. But I came across it again about six years later because somebody had done a very detailed analysis of the information flows within the cockpit of the aircraft during this incident. He had taken the cockpit transcript, broken it down into chunks of information, and had then analyzed the flow of information between members of the cockpit and between people in the cockpit and crews on the ground, the air traffic control officers who were communicating with them as well as other aircraft. He discovered that at peak load, the people in the cockpit were operating at about five times the cognitive level or the information-processing level of people in normal aircraft operation at peak load, which usually occurs during a landing. So it turns out that the people in the cockpit were receiving information, processing it, communicating among themselves, making 
decisions, and then communicating information out of the plane to people on the ground as fast as humanly possible. They were at their maximum cognitive load, in fact, and sometimes if you read the transcript, it seems like they almost became one organism. It was as if their brains melded together as they were making decisions to save this aircraft.

I' $m$ intrigued by this because I think that in the decision-making environments we've created for ourselves in this world, we're reaching our cognitive maximum in many cases. Especially in times of crisis, I would say that our leaders are finding themselves overwhelmed by the complexity of decisions they have to make, the amount of information they have to absorb, the range of decisions they have to take. It really is a much more difficult world to operate in, especially for our leaders, than it used to be. So that was the first connection point that interested me.

The second is a related point. It turns out that the cognitive load that these people faced was a lot higher because they had an inadequate knowledge of the nature of the system they were operating in. It turned out, after the National Safety Transportation Board had examined the wreckage, that the only thing controlling the direction of that plane was the differential engine thrust used by the check airman standing between the pilot and the co-pilot manipulating those engine throttles. But the pilot and co-pilot didn't know that. They continued to operate the wheels and columns in front of them because they thought they might have some residual control over the system. They continued to operate the plane as normal because they didn't know the nature of the damage to the system they were operating in. Therefore they had to spread their attention over a much broader range of things than they would have had to otherwise if they'd understood the system properly. Again, I think that resonates with our world frequently, in that we don't understand the complexities of the systems - ecological, technological, economic, sociopolitical systems - that we're living within; frequently we have to try everything in the hope that something will work. As a result, we spread our resources and our cognitive energy over so many things that we end up doing nothing very well at all.

The third connection point is the problem of time lags. Now Al Haines, the plane's captain, didn't know it at the time the explosion happened, but he sure learned quickly that a plane that has locked flight surfaces and can no longer steer itself but maintains power goes through an action that aeronautical engineers call a 'phugoid,' which is kind of a porpoising motion through the atmosphere - sort of like that. Now the key thing about a phugoid is that there is a time lag between the time that you change the engine thrust and the time that the plane responds in terms of changing its aerodynamic behaviour 
- going up or going down. For a DC-10 the time lag is somewhere between 30 and 90 seconds, a long period of time. Now as that plane was coming down on the runway at Sioux City, Iowa, the right wing was dipping, the co-pilot was yelling at the check airman, "LEFT. LEFT. LEFT. LEFT. LEFT. LEFT. LEFT." Because he wanted the check airman to increase power to the right engine so that the right wing would come up and they would land instead of crash landing. But of course the check airman couldn't do anything because the plane was responding to commands he had given it 30 seconds before. He was powerless at that point.

When you look at the complex systems that we're embedded in, you find that time lags are omnipresent, making management of these complex systems far more difficult. They're especially present in ecological systems. For example, the carbon dioxide that we are dumping into the atmosphere right now won't have its full effect on the global climate for another 50 to 100 years. The current warming that we see in the global climate has been caused in part by carbon dioxide that was emitted in the middle of the last century. But you also find this in economic systems. Probably the best example of a time lag that we're all familiar with is the lag between the time when a central bank intervenes to change interest rates and the point at which the economy responds in terms of increasing or decreasing its output of goods and services. In the American economy, that's assumed to be between six and nine months. We're all wondering now whether Alan Greenspan got it right this last time around, or if he waited too long to increase interest rates, then increased them too high, then ultimately did not decrease them quickly enough, with the result that he has done serious damage to the American and ultimately the Western economies. Time lags make it much more difficult for us to manage in this world.

The fourth connection point between this story and the real world is the problem of experts, the inadequacy of experts. Shortly after the explosion, when the plane was stabilized a bit and they were using differential engine thrusts, the pilot turned around to the first officer and said, "Get SAM on the line." SAM stands for 'System Aircraft Maintenance,' a group of designated engineers that United Airlines has to advise crews in crisis in the air. Within five or ten minutes, a group of engineers had gathered around a speaker phone in San Francisco and were talking to the first officer in United 232. First off, they requested a briefing on the situation, so the first officer told them everything. He said, "We've lost all hydraulic quantity and pressure. We don't know what to do. We seem to have very little control over this plane except by using differential engine thrust." The SAM engineers didn't know what to make of this, never having heard of an accident that compromised all three hydraulic systems. In fact, they had the first officer flipping through a thick flight manual 
trying to find something that pertained to their situation at the time. After a few minutes, the SAM engineers said, "Look. We have to go and think about this for a while . So we're going to sign off." So they disappeared, and then about ten minutes later, came back on and said, "Could you just confirm that you've lost all three hydraulic systems?"

The first officer shouted into the microphone, "AFFIRMATIVE, AFFIRMATIVE, AFFIRMATIVE," and then hung up. At that point, the crew realized that they themselves would have to generate the ingenuity to land the aircraft, and a remarkable job they did. There's not an insignificant amount of luck involved in this event; after the crash, they programmed the incident into a flight simulator and in 45 attempts, including a number of attempts with the original crew itself, they never got anywhere near the airport.

Thus, issues that I investigate, such as cognitive overload, time lags, and adequacy of experts, suggest that in recent decades our world has changed in a way that makes these problems more acute for us. My central argument is very straightforward: that the complexity, the pace, and often the unpredictability of events in our world are soaring, as is the severity of environmental stress. If we are to meet the challenges we face in this new world, we need more ingenuity. But we cannot always supply the ingenuity we need at the right times and places, and the result is an ingenuity gap. That's the basic argument.

Before I elaborate, what are some of the problems that I'm talking about? I divide them into three categories: problems at the global level, problems at the national or societal level, and problems at the individual level. One of the contentious claims I make is that there are common patterns across these three levels. In other words, the causes or sources of rising complexity and pace in our daily lives, at the personal level, can also be seen at the national level and at the global level. They are contributing to such things as international financial instability as in the Asian financial crisis of 1997-98. It's these common patterns that I'm trying to identify in my work.

At the global level, I'm interested in climate change, a problem that will probably affect every person on this planet, quite likely sooner than most of us realize. To address it effectively will require us to develop the most sophisticated and complex institutions that humankind has ever developed. International financial crises can be caused by an international financial system tightly coupled with 1.5 trillion dollars of hot capital sloshing around in it on a daily basis and hence prone to flip between stable and unstable modes as we saw in with the Asian financial crisis. Chronic zones of anarchy in the developing world caused by converging stresses, very much like those pilots experienced in United 232 in that cockpit, where you find societies that are 
faced with epidemics of tuberculosis and AIDS, diffusion of light weapons like rocket propelled grenades and assault rifles, rapid population growth, economic shocks from outside, weakened institutions inside these countries, and the convergence of all of these stresses and problems produce a breakdown of the process of economic and political development and ultimately a rise in violence. Over the last two years, we've learned that events happening on the other side of the planet in places where you have states breaking down and widespread social dislocation can penetrate right back into the core of our own societies.

At the national level, in Canadian society for instance, I'm interested in rising antibiotic resistance. This is a classic example of a race between our medical and epidemiological knowledge on one side and the pathogens that are affecting our species on the other, the bugs that are evolving faster than we can develop drugs to treat them. In many cases, it seems that those bugs are winning the race. Chronic health care crises - well, we know a lot about those in Canada. Persistent homelessness is an interesting problem: There is a widespread consensus in our society across all socioeconomic levels, across all classes to be crude about it, that this is a problem that needs to be solved, and yet for some reason our municipal, provincial, and federal governments cannot address this problem effectively. The data on the widening gaps between the super rich and everyone else are really quite astonishing. I don't think most people realize what has happened in the last 20 or 30 years, but I suggest that as the gap between the richest and everybody else widens, it will undermine our sense of identity and perhaps even lead to political instability in our societies.

In our daily lives, I'm interested in information overload. This is the thing that we confront every morning when we turn on our computers and find another 60 to 100 e-mail messages there. Many of us, especially those of us living in urban areas, now have the sense that there are simply too many stimuli, too many things coming into our lives, too many streams of information, that sometimes our brains literally feel overloaded. As you can see from my description of United 232, one of my arguments is that sometimes our brains literally are overloaded, that we are reaching our cognitive limits.

This is a pretty broad range of problems. How can I possibly link all of these together? I'm now going to sketch out the basics of what I call 'Ingenuity Theory' so that you can see how I bring all of these problems together and show the connections among these levels.

I start by defining 'ingenuity' and sets of instructions that tell us how to arrange the constituent parts of our physical and social worlds in ways that help us achieve our goals. I ngenuity is like recipes that allow us to take the stuff in our world, literally the stuff in the ground, and reconfigure it to make the things we need to solve our problems. My laptop computer, which has about as much 
computational power as was available to the entire American defense department in the 1960s, is nothing more than reconfigured rock and hydrocarbons. We've taken stuff out of the ground, and through a long and elaborate set of recipes, we've reconfigured it into this remarkable device. It's equally true with everything around us in this room - the seats you're sitting on, the clothes you're wearing, lights overhead - all consist of reconfigured materials from our natural world. If you want to think how amazing that is go camping sometime and sit in the natural world and think about what would be required to take all the stuff around you and make it into the things like laptop computers. It's really remarkable; we're extraordinarily good at that.

In my work, I focus on the requirements for these recipes or sets of instructions, what determines the kinds of instructions we need and how many instructions we need at the same time, and what things impede the flow of those instructions when and where we need them. Also, I make an important distinction between technical ingenuity and social ingenuity. Technical ingenuity consists of ideas or instructions for creating new technologies, like a laptop computer or more comfortable chairs or better lights or better internal combustion engines. We're really good at doing that as a species. We're not as good at producing ideas for how we arrange ourselves into societies and groups and institutions. That's what I call social ingenuity - sets of instructions for creating things like governments, political systems, or markets. Now, it turns out that social ingenuity is more important than technical ingenuity, but not only are we not as good at doing it, we also don't pay as much attention to it, because we're really fascinated by technology. But institutions ultimately are more important than technologies because you don't get the technologies you want until you have the right institutions designed. In particular, you're not going to get the flow of neat technologies like laptop computers or whatever you want unless you get your markets organized right so that your entrepreneurs are rewarded for the risks they take. They have to get the right price signals. But markets are very complicated institutions that require things like limitedliability legislation, property rights, judicial, court, and police systems that enforce contracts, monetary systems that are stable, stable banking systems - all of these things have to be provided if markets are going to work effectively. You need those first before you get the flow of technical ingenuity. That's why I claim that social ingenuity is more important than technical ingenuity.

I also make a distinction between requirements for ingenuity and supply. I'll talk more about requirements in a moment. Let me just say one thing about supply. It's important to understand what I mean here: By "supply," I mean ideas, ingenuity or recipes that are implemented and delivered. I think of society as pipelines; at the beginning of this pipeline is a generation stage 
where ideas are produced. That can happen in all kinds of places: in corporate laboratories, in government bureaucracies, in universities, in non-governmental organizations, or in local community groups trying to solve local problems. But then those ideas have to move along the pipeline to the implementation and delivery stage, and they're not supplied until they have been implemented and delivered. Unfortunately, you often get powerful special interests along that pipeline, acting to block the delivery, especially, of institutional reform, because when you change institutions, you change the power balance and the distribution of wealth within society. Powerful groups don't like that. So they intervene at various points to make sure that that doesn't happen. One of the results I have studied is how our political systems are changing to make it less and less easy for true institutional reform to occur. I'll return to that shortly.

We are left with a situation where I would argue that in certain circumstances our requirement for ingenuity shoots up faster than we can supply it. Not in all circumstances; sometimes in certain areas and with certain problems there is no ingenuity gap. We solve the problems quite satisfactorily. But in the kinds of problems I talked about earlier I would suggest there is a significant gap. Note one thing here: The supply is not leveling out, it's not flattening off. This is not an argument about limits to science or some kind of inescapable cap to human creativity. Human creativity is extraordinary and I believe our ability to innovate is still very strong. It's just that in some cases, we can't keep up; we're creating problems that are too hard for us, that are developing too fast and are too difficult.

Given this model, these basic concepts, we can ask some fairly straightforward questions. First of all, is our requirement for ingenuity rising? Second, if it is rising, can we supply the ingenuity we need? Third, if we can't always supply the ingenuity we need, what do those ingenuity gaps mean for our future? What are their implications? Fourth, what do we do about it? How do we fix this problem?

I argue that there are three principle forces driving our requirement for ingenuity, making our world more complex, faster paced, and sometimes more unpredictable: larger human populations; higher resource consumption; and more powerful technologies for the movement of people, material, energy, and especially information. These three changes together sharply raise the density, intensity, and pace of our interactions with each other and with our surrounding natural environment.

We can think of the world as consisting of networks. We are embedded in a set of systems - ecological, technological, economic, political, and social systems - each of which can be thought of as a network consisting of nodes or entities connected together with links. A node can be people, 
corporations, technologies, even whole nations. Over time, especially in the last two or three decades, we've seen a highly significant increase in the number of nodes in our networks and therefore a dramatic increase in the density of linkages among them. We've seen an absolutely exponential increase at the rate at which we can push energy, material, and especially information along those links. That causes the increasing density, intensity, and pace of our interactivity within these networks.

About a century ago, the French sociologist, Emile Durkheim, wrote about the inexorably rising dynamic density of societies. The concept is similar, except that in the last thirty years, we've seen a dramatic qualitative shift in the nature of human social systems. They have become complex in a way that's truly novel and has significant implications for our ability to survive. This is called a 'Complexity Transition,' and will be elaborated further later on.

Two of those three factors, larger human populations and higher resource consumption, have greatly increased our burden on Earth's natural environment, and the third factor, more powerful technologies, has shifted power from national and international institutions to individuals and subgroups. I call this the "power shift issue." If you want a dramatic demonstration, September $11^{\text {th }}, 2001$ showed that small groups of individuals can now destroy large groups of individuals. Within ten years, we may see that small groups can destroy whole cities. Thus, individuals now have access to unprecedented kinds of power - power to communicate, power to destroy, power to make things. That change has fundamental implications for the manageability of our societies. All these developments - increasing dynamic density, increasing burden on our natural environment, the power shift from large institutions to small groups - imply that we must cope with more complex, urgent, and often unpredictable circumstances. "Complexity" here means something specific: Complexity theorists talk about certain characteristics of complex systems: feedbacks, synergies, non-linearities, unknown unknowns, time lags. I'm not going to discuss all of these; you've heard about time lags in United 232. Let me just talk about a couple. Unknown unknowns arise when the system has become so complex that you don't even know what questions to ask anymore. You're ignorant of your own ignorance. It's like the problem I get when I look at my car engine now. I used to do a lot of work on cars when I was a teenager and understood them pretty well. But then I didn't own a car for a long time, for almost seventeen years. Then a couple of years ago I bought a new car - a nice European car, very fast, very sporty - and when I picked it up, the salesman came out and we opened up the hood. We looked at the engine and he said, "You can look at this but you can never touch it." For me, that engine, in its density of tubes and modules and wires all over the place where I 
couldn't even see the manifold anymore, represented a cluster of unknown unknowns.

The other concept I'd like to illustrate is the idea of non-linearities. Complex systems have the capacity to flip from stable to turbulent modes, often with very little prodding, with only a small permutation. In fact, complex systems often have multiple equilibria. They can sit in a number of stable states and move from one to another, often in very unpredictable ways. We see nonlinear behaviour around us all the time, but don't pay much attention to it because it's rather bothersome. It doesn't fit into our standard operating procedures very well. The collapse of the cod fishery off the east coast of North America is a good example of a non-linearity. The opening up of the Antarctic ozone hole is another non-linearity. The Asian financial crisis is a non-linearity in our international economic system. The exploding fan disk on U232 was a non-linearity. The dot-com implosion was a non-linearity in the stock markets. If anything characterizes complex systems, it's their capacity for non-linear behaviour, surprises that we can't anticipate. The one thing that shouldn't surprise us about the future is that it is going to be full of surprises. In this environment, we must generally make more and better decisions in less time than ever before, because the management of our relationship with this new world requires immense and ever-increasing amounts of social and technical ingenuity.

A couple of stories will illustrate what I mean. I'm going to talk about the climate because it's a good example of a non-linear system, using data derived from the Greenland ice sheet. As you know, Greenland is covered by a very thick ice sheet formed by the accumulation of snow that has fallen over thousands and thousands and thousands of years. As that snow has fallen, it has been compressed into layers of ice by the snow that has fallen on top of it. If you drill down and extract an ice core, you extract an archeological record of past climates. Scientists have examined the amount of snow accumulated each year and found that the warmer the climate over Greenland, the more snow falls. That is because warmer air holds more water, and as it still precipitates out as snow, you get more snow. We have evidence of an event around 11,500 years ago with a dramatic increase in snowfall at a point that's called "the end of the younger, driest cold event;" it's basically the end of the last Ice Age. That change in snowfall represents a 7-degree Celsius warming in a thirty-year period. Seven degrees Celsius in a thirty-year period. The difference between the current average temperature on the planet and the coldest period of the last Ice Age 18,000 years ago is 5 degrees Celsius. This is a monumental change in global climate. It turns out that at that time, there was a wholesale reorganization of atmospheric and ocean circulation systems all around the 
planet. We think we know why that happened, and we're concerned that if we push the temperature higher on this planet by another degree to a degree and a half, we could see that kind of flip in the organization of ocean currents in the North Atlantic which could trigger reorganization elsewhere on the planet. The key thing about this is that it is hard-core evidence of the non-linear behaviour of the global atmosphere. Don't assume that as this planet warms up over the next century it will be a nice easy ride into the greenhouse future. It's going to be characterized by sharp sudden shifts which will make adaptation vastly more difficult.

For the second part of the story, we go to the other pole of the planet, to a lake in Antarctica called Lake Vostok which is all frozen except for a little bit of water at the bottom. In the 1980's, Russian and French scientists started drilling into the ice sheet over Lake Vostok to extra ct an ice core. Later, American scientists finished the drilling, extracting an ice core that was almost four kilometers long and stopped just above the water. That whole ice core represents 420,000 years of time. The scientists made some very interesting discoveries, because they were able to extract air bubbles from each year's layer of ice and determine the carbon dioxide concentrations of various years as they went back into the past. So they had a record of carbon dioxide concentration going back 420,000 years, and using some clever chemistry, they were able to determine the temperature of the atmosphere at the time the snow fell. They found a very close correlation between changes in carbon dioxide concentration and changes in temperature. Now, we all know that correlation doesn't necessarily mean causation, but as lawyers would say, this is good prima facie evidence of a causal relationship between the two factors.

A sharp, sudden change has happened in the last 150 years. With industrialization, we have increased the concentration of carbon dioxide in our atmosphere by about $30 \%$. The temperature is increasing too; we've seen an increase in temperature of almost one degree Celsius since 1900. This is where we're going in the future, and that's locked in, guaranteed, within the lives of our grandchildren. That represents just over a doubling of carbon dioxide in the atmosphere from pre-industrial levels, probably by about the year 2050. Now, although our atmospheric models of global warming are organized around a doubling of $\mathrm{CO}_{2}$, most atmospheric scientists say we're not going to stop at a doubling. Given current development patterns on this planet, we're going to triple or quadruple our carbon dioxide concentration, and in that case, I would suggest that we're going to see some pretty dramatic effects on this planet in the next little while.

What's the point here? The point is that human beings are now, in an unprecedented way, major actors on this planet. We move as much dirt and 
rock on this planet on an annual basis as nature does itself. We have doubled the amount of reactive nitrogen in the atmosphere and increased the amount of carbon dioxide by $30 \%$. We are major actors. We don't know the implications of that and the only thing we can be certain of is that it will make our problems harder in the future. We're going to need more ingenuity to adapt to this new world.

Can we supply that ingenuity? I break this question into four parts; in my book, I devote a chapter to each one. I'm interested in brains because brains are the engines of our ingenuity supply, where all those ideas start. We need to go back and look at the evolution of the hominid brain over three million years and ask, "Are the characteristics derived from that evolutionary heritage suitable for the kinds of problems we've produced for ourselves today?" I deduce that in some cases, we don't have the right kind of brain for today's kinds of problems. Science and technology are very important if we're going to solve our problems, but we shouldn't assume that they will always solve our problems. Many people seem to think that science and technology will rescue us, that if we have climate change, we'll put mirrors in space or dump iron into the ocean and create phytoplankton blooms that will suck carbon dioxide out of the atmosphere - or something. But science and technology don't always solve our problems when and where we need them solved.

One of the best examples of this is cancer. We've invested 40 billion dollars in cancer research since Nixon declared his war on cancer in the early 1970s and we all still know people who are getting cancer. Necessity is not always the mother of invention and we shouldn't assume that science will save us at some point in the future.

Markets are important for the reasons I suggested before. We need markets organized so that they give the right price signals to our entrepreneurs. But frequently our markets are riddled with what economists call "market failures." They don't give the right price signals. The best example we have right now is gasoline prices. If we really cared about the future, about the climate future for our children and our grandchildren, our gasoline should be far more expensive now. It should include some of those future costs and then we'd conserve, we would invent new technologies that would allow us to reduce our carbon dioxide output into the atmosphere.

Finally, politics is important, because politics often determines whether those important ideas to solve our problems actually get implemented or whether they get blocked in that ingenuity supply pipeline.

What does this mean for educators? The first point is that we need to put on a new set of conceptual lenses that allow people to see the world on a human scale, but including the micro and the macro scales. We don't see small 
things anymore and we don't see big things, especially if we live in cities. Think of Hong Kong and Beijing. One of the things we do in cities, especially in the developing world, is to generate huge amounts of smog and haze. Haze now blankets a large part of the world, but that brown sludge you see on the horizon is not normal. We also generate staggering amounts of light in urban areas, so we seldom see stars anymore. We've all had the experience on a clear, dark, summer night in the country side when we've looked at the sky and at the Milky Way and thought, "Oh, my God. That's just an astonishing thing." When we see the Milky Way, the first thing we think of is "My God, we're small." But we've lost the sense of awe and prudence, a sense of our true place in the universe, and so we often misunderstand the character of the problems we face or don't even see the problems at all.

I'm going to give you a concrete example: frogs. We have a worldwide die-off of amphibian populations going on, especially of frogs, from Queensland, Australia to Costa Rica in Central America to California to Newfoundland. All over the world, we're seeing a precipitous decline in frog species. I had an ecologist from Newfoundland sitting in my office one day and he said, "It's astonishing. There are just no frogs any more." Well, the frogs are probably dying because of a combination of stresses: a thinned ozone layer that has increased ultra-violent radiation of the surface of the planet and weakened the reproduction systems of these frogs, pollutants in the environment that weaken their immune systems, harvesting for food, destruction of habitat all of these things are happening simultaneously and one of the results is we're seeing a decline in frogs. But most of us don't know that because we're so busy living in our self-referential world that we don't see frogs any more. Most of us don't notice that there's a problem out there. Frogs are like a canary in the coal mine. They're busy chirping away but nobody's listening because we're so wrapped up in the big ' $I$ '. It seems to me that this is something that educators must confront directly.

So what does the ingenuity gap mean for our future? I think it widens the gulfs between rich and poor and between powerful and weak people. All of us in this room are educated, wealthy, and adaptable enough to deal with the complex changes that our world throws at us. Most of us probably have rich social networks to draw on when the going gets rough. But for an increasing portion of our societies and of the planet, people are being left behind. On a planetary scale, five to six hundred million people in sub-Saharan Africa are completely off the radar screen now. Nobody is paying attention to them. A major famine is going on in sub-Saharan Africa right now in Malawi, Botswana, Zambia, and Zimbabwe that threatens 15 million people. Have you heard about it? Are people paying attention? No. Increasingly within our own societies, 
some groups of people just can't keep up with the kinds of changes we're seeing. This produces a fragmentation of our shared reality. Never before have we been so connected together on this planet and never before have we been so far apart in our realities - with web-ware designers in Silicon Valley living right next to women in South Africa who have to walk five kilometers every day to get their water, with bond traders in the City of London living right next to slum dwellers in Sao Paolo living right next to us in this auditorium right now. Unfortunately, we've learned from the last couple of years that these different worlds won't stay isolated from each other. We're packed cheek by jowl on this planet now, so that the problems, dislocations, and issues that are arising on other sides of the planet are going to visit us in our own lives here.

So what should we do? This is where I get to my last three points. I draw first on the story of United Flight 232, because Al Haines identified a number of factors that allowed him to land that plane. The first was luck: The accident occurred in daylight, the weather was good, and there was an airport nearby. There also happened to be a check airman on board. Those things helped them get that plane on the ground. A second factor was planning: Just a couple of weeks before, the crews on the ground at Sioux City, Iowa had done a full dress rehearsal for the crash-landing of a wide-body aircraft on the shortest runway of that airport. Another factor was co-operation: Some years before, United Airlines had implemented a program of training of its crews to react in a crisis in a co-operative and not hierarchical way. So when that accident occurred, everyone within that cockpit instantly started to co-operate to solve the problem. The hierarchy was flattened. The captain had to make some final decisions in some cases, but he had been trained to listen. Al Haines says that this was absolutely critical to get that plane on the ground. Then the final thing, which Haines did not mention, but which I consider very important, was experiential knowledge. This is something we have to emphasize as educators.

According to the results of the simulation tests, if Captain Haines had increased power to that right engine a second earlier or a second later, he would have lost control of the plane. When I asked him, "How did you know when to do it?" he answered, "Oh, well, I guess it was just luck." I don't think it was luck. It was the fact that he had been flying those planes for tens of thousands of hours, until the DC-10 was like an organic extension of his body. He had extraordinarily rich understandings of that machinery - experiential knowledge. I think we need to do more to cultivate wisdom in our societies, the wisdom that comes from working with complex systems for long periods of time so that you can recognize their patterns of behaviour, so that you have an intuition for what they're going to do and how they're going to respond. We need, too, the wisdom that comes from integrating reason with emotion, because it's for a 
purpose that we've evolved to have emotions. We've evolved to have emotions because they help us survive. Fear and awe and wonder and dread help us survive, helped us survive on those plains of Africa. But although we've left a lot of emotional responses behind, wise people are still able to integrate that extraordinarily rich emotional repertoire with their reason when solving the problems that we face.

My second concluding point is about sustainability: education for sustainability and the recognition of our connectivity through time. What does sustainability mean in terms of the ingenuity gap? We can think about it this way: If you're not living sustainably, you're not planning far into the future. Your time horizon is proximate, one or two years, or four years in the future perhaps at the most. If you've got a problem, such as for example, a declining fishery like Newfoundland's, how do you respond to it? Well, since you don't plan far into the future, you respond by increasing the size of your fleet of fishing boats, getting better sonar so you can track the fish, building better nets so you can catch them, and so that involves a slow incremental increase in ingenuity over time. But then the system breaks down. You have one of those non-linearities because you haven't been thinking far into the future. Just at that point where you see that sudden sharp rise you get a dramatic increase in your ingenuity requirement - perhaps an infinite increase. Perhaps you can't solve your problems any more. This is what sustainability means. We move our time horizons way out into the distance; we're concerned now about the well being of people a hundred, a hundred and fifty years in the future. We want to make sure that fish stock is still able to provide fish in that period of time. But that means we have to adjust our technologies and institutions in a major way now. We have to invest in thinking about how to live within the limits of that resource base. It's easy to see why sustainable development doesn't get done; it's because there's a big investment in the present. It means you have to challenge the vested interests in a major way in the present. But I think one of the things that we can do as educators is help people recognize the implications of our actions well out into the future and the importance of starting to make changes to our technologies and institutions in the present - moving those changes into the present just as that green curve shows.

I think the final thing we need to do as educators is to broaden our conception of values, because the difficulty and character of the problems we face in this world are shaped fundamentally by the kinds of values we adopt. For instance, if we decide that the kind of life we want, the good life as we define it, includes two SUVs in the driveway, a three-car garage, five bedrooms with four washrooms and yearly trips to the Caribbean, and we want to do that for all of the ten to eleven billion people we're going to have on this planet 
eventually, that's going to take a lot of ingenuity. We're going to have to be very smart to squeeze all of those services out of the limited material resources on this planet - to reconfigure them in a way that will provide all the stuff for ten to eleven billion people. We're probably going to have to live by lots of regulations. We're going to need very good technologies, very constraining institutions in a lot of ways. But we might decide, 'Well, you know, maybe that's not what's really important to a good life. Maybe we can be really happy with less material stuff.' Then all of a sudden, other options start to open up because we don't need so much pure technical ingenuity to provide the material well-being.

Now, the last thing I want to consider is how we think about values, because I think they influence fundamentally how we're going to address the problem of the ingenuity gap. There's a tendency within our common discourse to think about values as what I call simple preferences. These are what economists would call "utilities." I like vanilla ice cream more than chocolate ice cream. Unfortunately, that's about where the discussion of values stops a lot of times. But clearly there are other kinds of values that are important - moral values, values that relate to how we deal with each other in our societies, issues of fairness and justice for example - those values are very important. They don't get talked about very much, but at least they get talked about a little more than this third category: the existential or spiritual values that relate to what we regard as the source of meaning in our lives, the relationship between us and the cosmos, what the point of the whole exercise is. We learn by the time we're about ten that we shouldn't ask these questions, and we learn quickly from the expressions on the faces of adults that we're supposed to go somewhere else, perhaps to religious institutions or something, to find out the answers to those questions. So we go to those places and we're not given a place to think; we're told what to think. Maybe if we're lucky, by the end of our lives as we start to get intimations of mortality, we start to realize, "Wow, these questions are pretty important." Then we go back to investigate them a bit. But for the most part they are entirely marginalized within our societies. And yet if we want to think about our notion of the good life - what is bringing meaning into our lives and ultimately therefore what kinds of material satisfactions we want, whether two SUVs for example are really important, the answers start at the level of existential values. That's where we need to start. Unless we talk about those issues among ourselves, we may never reach a real consensus. We have to talk about them to start re-thinking the point of our social existence and individual existence. If we never discuss those questions, then all that gets talked about are the simple preferences, and human beings become defined simply as consumers or more crudely as walking appetites - as people who are driven by 
their hedonistic desires for some things over other things. The economists essentially win the day.

I conclude that a highly critical requirement for us in education is to broaden our conception of values - to educate for a broader conception of values in the future. If we don't do that, I can't see how we're going to address a lot of the problems that I've discussed in this presentation today. Thank you very much.

\section{Question \& Answer}

Question 1: With the problems of terrorism, can you see a reinvigoration of the nation state as a decision-making institution? What can we do to talk about democratic values with the military and especially the politicians who dictate the role of the military in society?

It's a great question. The state is really important. Sometimes I don't like where people take the state, but as an institution it's important because it generates the public goods that allow for our well-being. It solves what economist would call "collective action problems." We really need things like health systems, road systems, security, control of epidemic diseases and things like that, but none of us is really prepared to pay a large cost as individuals unless we know that everybody else is going to as well, so there's an inevitable free-rider problem. We always want to hold back and let other people take care of the problem. What the state does is co-ordinate action so that we're all part of it together and the problem gets solved. My concern is that we're seeing an inexorable weakening of state institutions because of the power shift I spoke about earlier - the increase in power due in part to communication technologies and in part to the diffusion of technologies to destroy. Now a lot of the time, the increase in communication ability is a very good thing because it allows us to participate more fully in democracy, to communicate and organize ourselves more effectively. There should be - a lot of people assumed there would be reinvigoration of democracy as a result of the internet, for example, and all the new communication technologies from fax machines to cell phones and things. But I'm not sure it's going to work out like that. I think it's more likely that what we're creating is a kind of electronic cacophony or electronic gridlock. Decision makers within our democratic institutions are absolutely overwhelmed now by the flow of information coming in. In the United States, 1998 figures showed that representatives in the House of Representatives would get up to 5,500 e-mail messages a month, senators up to 70,000, and congress as a whole 
80 million e-mail messages a year. Until six to eight months ago, they responded to every one. Policy makers are overwhelmed. Now we have a set of democratic institutions which are critical to the functioning of the state in Western society that were developed or evolved during the $18^{\text {th }}$ and $19^{\text {th }}$ centuries when people traveled at the speed of horses at a maximum and when information was transferred almost wholly by mouth because most people weren't literate. Now people can travel to the other side of the planet in less than a day, and they transfer information by the gigabit. We have hyperempowered citizens and institutions from over a century ago - two centuries ago. A big ingenuity requirement is the need to rethink our collective decisionmaking process effectively so that we can decide how we're going to solve our problems and include these hyper-active and hyper-empowered citizens effectively within that decision-making process. We need to strengthen the state rather than weaken it. At the moment, many people are withdrawing as participants because they see that the system isn't working. It's losing its moral legitimacy, voting turnouts are going down, nobody interesting and competent of high caliber wants to go into politics any more, and so we're seeing a steady erosion of the quality of our political institutions and over time, an erosion of the strength of the state. That's really bad news. The other part of this, of course, is that when you have all of these hyper-empowered groups all over the place, it's very difficult to solve problems with collective action. It's very difficult even if you have a competent state to get everybody together to actually deal with something like climate change, as we can see in Canada right now. So my sense is that we've got a real problem here, and we have to start thinking really creatively about new forms of democratic participation in our societies.

Question 2: I want to ask a question about the economy and some of the problems you've raised. Do you think that we need to look for ways to develop alternative economic systems or do you think we can simply accomplish what we need to accomplish by regulating the capitalist mode of production?

I'd like to answer that question by referring to the data on income distributions from the United States over the last forty years. These are from U.S. National Census Bureau data on mean family income in 1997 dollars, so they're controlled for inflation. The population is divided into quintiles (5ths), from about 1967 to almost 2000. (The latest figures aren't out but they'll be about the same in terms of trends.) The bottom four quintiles - $80 \%$ of families in the United States - have seen very little or no real increase in their income. The bottom three are essentially flat, and the fourth is almost flat, but the top 
fifth of the population has gained an increase of about $50 \%$ in its income, while the top 5\% of the families have seen an increase of over $100 \%$. This represents a pretty fundamental change in the structure of distribution in our societies.

I think, to answer your question, that it is fundamentally a function of the nature of capitalism. I'm not sure that it's essential to capitalism, but it means that to avoid this situation, which I think ultimately is very dangerous to our society, we have to watch what's happening very carefully and we need strong states to deal with it. Why is this bad news? Well, among other things, it's bad news because increasingly, you're going to find that the top portions of the socio-economic system of the distribution are not willing to contribute to the generation of public goods, because they can buy whatever goods they need privately. Parks, recreation, health care, roads, security - they'll just buy them privately. Increasingly, it undermines our common sense of identity and if there's one thing that we need to solve our common problems it's a sense of 'we-ness' - that we are together in these problems and need to solve them together. So over time, this is really bad news for ingenuity generation, for solving our problems, and even for political stability.

Why is it happening? One of the critical reasons is that in our modern capitalist economy, markets are so large that those who are best at producing whatever they produce can sell essentially to the whole planet or at least to very large markets. But everybody who is second-ranked or further down the ranks doesn't get rewarded. So you get a winner-take-all economy - rewards tend to go to the very top-echelon producers and everybody else suffers. Just to finish my comment on this question: This economic gap is one of the problems we have in the current global capitalist system because it is happening not only within the United States, Canada, and other Western countries, but around the world. We see this widening of the gap.

But we also have the problem of a capitalist system that seems to be pushing at the outer limits of the ecological thresholds of the planet. We have a system that has a chronic problem maintaining adequate demand. For example, one of the problems we've got is that the bottom four quintiles are not increasing their income sufficiently to maintain adequate demand within the economy. So what do we do in response? Well, we generate a psychology of hyper-consumerism, to turn everybody into walking appetites. We try to get them to spend all of their money; we don't want them saving any money, and we don't want the savings rate to go up in the United States because the whole world economy now depends on the American consumer. Well, so on one hand, we have to maintain through-put in the world economy because it's only stable if it's growing; if it isn't growing, these differentials are going to produce real political and social instability. On the other hand, that increase in material 
consumption is producing problems like the Green House problem that I mentioned before. That is pretty close to a fundamental contradiction. We are on the brink of a deflationary spiral in the Western and the world economy right now. This is a new situation, what Paul Krugman calls the "return of depression economics," and the way we solve it is by pumping up consumption. We want people to buy SUVs. At the same time, we're having the worst drought that has ever been experienced on the prairies, and climate change is starting to show its face all over the planet. I think it's reasonable to say the signal is appearing from the noise. This is a serious contradiction. I'm not sure whether it's an essential contradiction in capitalism, but we certainly need to revisit some of the deeper principles of the economic system we've created.

Question 3. You talk about people being overwhelmed and indeed they often are, but they also seem to be "underwhelmed" in that the information they get is often summarized and seldom explained in depth. This isn't really new; even in war-time, most news was summarized, but today it seems to be even more the case, and it's something that as educators, I think we should be fighting against. You mentioned microcosm and so forth in doing that. Do you have any "help" as to how to combat this?

Well, one of the things - and this is not a bad way to conclude I suppose - one of the things that people have found frustrating about my book is that I don't provide a checklist of answers at the end. In fact, it would be a bit odd for a book that's an extended argument against arrogance to say at the end, "Oh, well, I've got all the answers." I'm not sure of the answer to this one, but we do have a critical problem, rather like the one about the capitalist system. The problem is that we've improved our ability to transfer information practically infinitely, but our basic cognitive capability hasn't improved. We have probably increased our information-transfer capability a hundred million fold in the last twenty years. Well, what do we do in that situation? Here we are sitting in this tidal wave of stuff that's piling up at the front doors of our cerebral cortex. What do we do? We hyper-specialize, we task-switch, and we abbreviate. We all task-switch, this is what multi-tasking is all about, right? We all do a little bit of this, a little bit of that, go back and forth - it's really inefficient, it lowers your cognitive effectiveness - all the tests show that you're actually a worse driver when you're talking on the cell phone. But we're all doing it because we've got so many things going on, and this gets directly to your point. We abbreviate, we shorten our messages. We see it in e-mail messages. They're staccato phrases; we lose the depth of communication with people. It appears from cognitive research on the size of the human brain and 
looking at other hominids and things that the normal size of our cognitive community - people that we can reasonably know something about, given the size of our brains - is about 150 . But now we can have infinite communities. People I haven't spoken to in thirty years are popping up on the internet, right? I publish a book and I do the stupid thing of having my e-mail address on it and anybody in the world can contact me now. We have a cognitive community that is essentially infinite in size. It can involve thousands of people, even for somebody who is not terribly active on the internet. So what do we do? We abbreviate. Everything is getting abbreviated. Information within our news systems is getting abbreviated. In the last 30 years - this is one of the statistics I quote in my book - the length of Time magazine cover stories has gone down $40 \%$. The length of Scientific American research articles - their principle ones - has gone down 30\%. New York Times opinion articles have gone down 25\%. A New York Times article now averages 575 words. You tell me what you could say about the world in 575 words. We have a world that's more complex, that requires more sophistication of thought, more subtlety, more lines of information and evidence integrated to try to address our problems, and we have less and less time to talk about those things. Because what's happening? Editors are responding by shortening those articles. They're responding to what they know about their audience, that it has no time to read any more. Most people don't read long texts. "I've got five minutes between one thing and another, I can read 575 words, so I'll read this." You get a little snippet of an idea, a snapshot of information - that's not going to help us solve our problems. So somehow, if we're going to reinvigorate our collective institutions of the state and our democratic decision-making, we have to return to some deliberative mechanisms. We have to give people, communities, and societies the space in their lives to actually think about things, and the time to do so. Again, that's a big ingenuity requirement in terms of designing our collective institutions, and what I'm trying to do in this book is raise the issues so that we can work on them together. 


\title{
Promoting Cooperative Learning in the Classroom: Comparing Explicit and Implicit Training Techniques
}

\author{
Susan Mitchell \\ Vera E. Woloshyn \\ Anne E. Elliott
}

\begin{abstract}
In this study, we investigated whether providing $4^{\text {th }}$ and $5^{\text {th }}$-grade students with explicit instruction in prerequisite cooperative-learning skills and techniques would enhance their academic performance and promote in them positive attitudes towards cooperative learning. Overall, students who received explicit training outperformed their peers on both the unit project and test and presented more favourable attitudes towards cooperative learning. The findings of this study support the use of explicitly instructing students about the components of cooperative learning prior to engaging in collaborative activities. Implications for teacher-education are discussed.
\end{abstract}

Three decades of research document that instructing students to use cooperative learning techniques improves both their academic and social performances (Antil, Jenkins, Wayne, \& Vaasy, 1998; Blumfield, Marx, Soloway, \& Krajcik, 1996; Kahl \& Woloshyn, 1994; Shachar \& Sharon, 1994; Sharon, 1994; Slavin, 1990, 1995). It is also widely accepted that cooperative learning involves more than simply placing students into groups (Kagan, 1990; Natasi \& Clements, 1991; Thousand, Villa, \& Nevin, 1994). Specifically, Johnson and Johnson (1990, 1991, 1994) have long argued that students must be taught five critical skills or components in order for them to collaborate effectively. These components include: (a) Positive interdependence where an individual student's success is dependent on the success of his or her group; (b) Positive face-toface interactions where students develop a sense of sharing, understanding, and accumulated group knowledge; (c) Individual accountability where each student is required to demonstrate his or her own learning; (d) Interpersonal and smallgroup skills including effective communication, conflict-resolution, and

Vera E. Woloshyn and Anne E. Elliott are Associate Professors of Education at Brock University, where they conduct research on explicit strategy instruction and children's social development. Susan Mitchell is an elementary teacher and recent graduate student in Education. 
decision-making; and (e) Critical reflection on academic and social processes.

The question arises as to how educators might best teach students these somewhat ambiguous skills. It is well documented that students best learn the strategic processes associated with reading and writing best when instruction is explicit (e.g., Butyniec-Thomas \& Woloshyn, 1997; Gallagher \& Woloshyn, 1999; Harris \& Graham, 1992; Pressley et al., 1992; Woloshyn \& Elliott, 1998). Briefly, such instruction requires teachers to model critical learning strategies or processes and to provide students with information about the parameters associated with their use. Explicit instruction also includes providing students with multiple opportunities to practice using those critical strategies or processes. By reflecting on the quality of their work before and after using strategies, students are encouraged to "discover" that strategic approaches are superior to non-strategic ones. Explicit-strategy instructors often share stories of their own learning experiences, highlighting instances where their successes could be attributed to the use of strategic processes. Finally, explicit instruction requires educators to continually prompt their students to transfer and generalize the use of relevant learning processes across the curriculum.

A review of the cooperative learning literature, as well as the supporting teacher-materials and resources, suggests that many critical skills associated with cooperative learning processes may not always be presented to students in an explicit fashion (Battistich, Solomon, \& Delucchi, 1993; Johnson \& Johnson, 1994; Kagan, 1990b; Slavin, 1994; 1995). Rather, information about these learning processes seems to be provided at an implicit or incidental level. For instance, prerequisite skills (positive interdependence, positive faceto-face interactions, individual accountability, interpersonal and small-group skills, and critical reflection) are not labelled or taught consciously as part of the planned curriculum and students are usually not provided with examples of "how," "when," and "where" to use them. Consequently, students may not fully acquire these skills or readily realize that the cooperative processes they have completed for one task can be transferred to similar learning situations. Such situations can prove frustrating to students and to teachers alike and may impede the widespread use of cooperative learning.

Research also supports the importance of providing students with a "structure" or "format" for discussion while working cooperatively. For instance, Kahl and Woloshyn (1994) documented that students who received instruction in both question answering and cooperative learning prior to completing an academic activity demonstrated superior learning to students who received only question-answering or cooperative-learning instructions.

Similarly, research carried out by Meloth and Deering $(1992,1994)$ and Berg (1993) confirm that students' cooperative learning experiences can be enhanced 
when they are provided with specific training with respect to how to engage in effective cognitive processes.

The primary purpose of this study was to investigate whether providing students with explicit instruction in the "socially-based" prerequisite skills or components of cooperative learning would facilitate their academic performance and promote more positive attitudes towards cooperative learning. This approach is in contrast to the more common form of implicit instruction where students are focused on completing the learning task rather than focused on the collaborative process.

\section{Methods}

\section{Participants}

Twenty-four grade-4 students and 24 grade- 5 students ( 29 males, 19 females, $M$ age $=9$ years 7 months) participated in this study. All students were native English speakers with parents of lower- to middle-income socio-economic status. While all students had completed group activities and had been provided with opportunities to work with their peers in the past, none had been provided with formal instruction in cooperative learning. Half of the students in each grade were assigned randomly to either the explicit or implicit cooperative-learning training conditions. Students were then assigned to heterogeneous groups within their grade levels. These groups consisted of four students each for a total of six groups in each condition. Students' classroom teachers confirmed that the groupings contained children of mixed academic abilities. All training and instructional sessions were delivered by the first author, who has over a decade of experience teaching in the elementary grades.

\section{Cooperative Learning Training Conditions}

Explicit-training cooperative learning condition. Students in the explicit condition received a total of ten 50-minute cooperative- learning training sessions. Specifically, seven of these lessons involved explicit instruction and practice of a prerequisite cooperative learning skill or component (e.g., learning styles, working roles, social roles, reflection). As part of these lessons, students were asked to identify the social skills that people need in order to work together well (e.g., listening, complementing, encouraging). During each lesson, the primary researcher modelled these critical skills and instructed students to demonstrate what they "looked like" and "sounded like." As part of these lessons, students also discussed the benefits 
associated with cooperative learning, how it differed from other formats of learning, and when it was an appropriate learning tool. For example, students were provided information about individual, competitive, and cooperative learning styles and discussed why the latter was a preferred method for learning. They identified that life in a global world was interdependent and problems such as pollution could only be solved if people worked together. They also identified instances where they had learned from and taught family members and friends. The primary researcher shared instances from her life when she worked cooperatively with others and contrasted the benefits associated with those working experiences to other instances when she worked alone.

Students also participated in short "role-plays" demonstrating behaviours associated with each learning style or approach. The primary researcher modelled language associated with each approach (e.g., "me instead of you" for competitive; "me alone" for individual; "we as well as me" for cooperative), with students encouraged to adopt cooperative terms (e.g., "I can attain my goal only if you attain yours"; "We share materials and ideas"; "We care about the success and effort of our group"). Students also spent considerable time exploring the concepts of accountability, motivation, and group responsibility. To this end, the primary researcher modelled what appropriate levels of concern, interest, nurturing, and constructive feedback might look like in a group, with students, in turn, participating in relevant role plays. Throughout these series of lessons, students created a "team" identity and practiced preparing themselves to engage in a group activity in an expedient fashion (e.g., gathering and sharing materials, negotiating, and assuming relevant roles).

Students also participated in role-plays and reflective discussions of past experiences in order to develop skills in academic and social roles that they would need to assume when working cooperatively. For instance, the primary researcher modelled such roles as "recorder", "summarizer", "encourager", and "monitor" and provided opportunities for students to assume each position. Similarly, the researcher modelled and provided opportunities for the students to practice such communication techniques as "think-pair-share" (i.e., students reflect on a topic individually, share their thoughts with a partner, participate in whole-group discussion), "round robins" (i.e., individual students formulate a written response to a printed message and circulate their response to another member who reads and adds his or her commentary and ideas), and "corners" (i.e., unique perspectives on a given topic are represented in each corner of a square, with students assuming the position of the corner they occupy).

For the final three lessons in the series, students participated in "teambuilding" activities where they were required to complete an interest inventory/ 
interview; build a plasticine boat that would hold ten marbles, and create and present an original product. During each session, students reflected on and completed an evaluation form monitoring their contributions to the team, their ability to communicate effectively with each other, and their general enjoyment of the group process. Group members were also encouraged to reflect on alternative methods for solving the identified problems.

Implicit- training cooperative learning condition. Students in the implicit training condition also participated in ten 50-minute cooperativelearning training sessions. During the first session, the primary researcher provided students with information about the three approaches to learning (individual, competitive, and cooperative) and informed them that the latter was associated with increased academic and social performance. Students briefly discussed the importance of working collaboratively and practiced basic communication skills as listening, taking turns, and staying on task. Students also practiced completing an evaluation form for the purposes of reflecting on group processes.

The remaining sessions consisted of "team-building" activities designed to establish trust and rapport among students (e.g., interviewing, team discovery, desert-island decision making, boat construction, creating and presenting an original product). These activities are consistent with those typically used in classrooms when preparing students to work cooperatively (e.g., Sharon, 1994). Students in this condition did not explicitly discuss the advantages associated with cooperative learning or the parameters associated with its use. Furthermore, the primary researcher did not model or explicitly label cooperative-learning skills or components nor were students provided with extended opportunities to practice them.

\section{Famous Artists Curriculum Unit}

After participating in either the explicit or implicit cooperative-learning training sessions, all students completed a famous-artists unit. The unit extended over eight days, with each lesson lasting 60 minutes. During each lesson, the students worked in the same cooperative-learning groups that they formed during the training sessions to study the "works and times" of six famous artists including Rembrandt, Monet, Van Gough, Da Vinci, Picasso, and Gauguin. The famous-artists unit was part of students' regular school curriculum and represented their first formal experience studying these artists.

On the first day, students were provided with information about the guidelines and requirements of the famous-artists unit. Specifically, the primary 
researcher described each requirement and recorded this information on chart paper that was displayed for the duration of the unit. Students were also told that they would complete a summative test assessing their knowledge of each artist.

For each subsequent class session, students were provided with a onepage information sheet outlining critical information about each artist

(Appendix A). Students were instructed to use this information as part of their unit project. Additional texts and materials about each artist were also available in the classroom. Each day, students were instructed to complete five activities that cumulatively would form the basis of the famous-artists unit project.

Project requirements included having students describe three-to-five facts about each artist's work, family life, and cultural background. Students were also required to identify and describe three paintings associated with each artist, as well as provide three "interesting" facts about them. Finally, students were instructed to illustrate an important aspect of each painter's life. The researcher collected students' work at the end of each session.

Famous-artists unit project. Each cooperative group was provided one additional class session to complete its famous-artists project. Students were encouraged to present information in creative/innovative formats such as webs, charts, mind maps and to include a title page and table of contents. Two educators, with over 15 years of teaching experience each, assessed the students' projects across six criteria: answer completion, answer elaboration, creativity, organization, illustrations, and appearance. Briefly, the "completeness" score reflected students' ability to complete all the project requirements, "elaboration" measured whether students had gone beyond the project requirements, "creativity" captured whether students used a variety of formats to present information, "organization" assessed the order of presentation and flow of information, "illustrations" included the use of titles and labels, and "appearance" provided an overall measure of the neatness and professional presentation of the project. For each criterion, students were awarded a score out of five. For instance, students were awarded a score of five if their illustrations were coloured, clearly labelled, and included extra details and efforts. Contrarily, students received a score of one if their illustrations that were not coloured, did not contain accurate or complete labels, and contained no additional details. Students' projects that had some colour, details, and met the minimal requirement of one illustration per artist received a score of three. Each project was awarded a total score out of 30. The teachers were unaware of students' assignment to the experimental conditions, with all scoring discrepancies being resolved through discussion. 
Promoting Cooperative Learning in the Classroom

\section{Attitudinal Questionnaire}

The day after completing the famous-artists unit project, students completed a 20-item questionnaire assessing their attitudes and beliefs about cooperative learning. Students responded to each item using a 5-item Likert scale where "1" indicated that they strongly disagreed and " 5 " that they strongly agreed. The students were instructed to respond as honestly as possible and were assured that their responses would in no way reflect their project grades. Instead they were told that the questionnaire would provide the researchers with valuable information about the usefulness of cooperative learning when working with grade-4 and grade- 5 students. The questionnaire consisted of items assessing students' perceptions about their ability to work cooperatively (e.g., I know how to work in a cooperative group; I stay on task when working with others; I accept everyone's opinion in my group), benefits associated with collaborative endeavours (e.g., I am better at solving conflicts now; I learn well when working collaboratively; Knowing how to work cooperatively will help me when I am older), and overall enjoyment of the cooperative process (e.g., I enjoy sharing my ideas with my group; Cooperative learning is fun; I wish we could work in cooperative groups more often). Students also responded to five, open-ended questions (e.g., I have learned the following about cooperative learning... about others... about myself, The best/worst aspect of cooperative learning is....). There was no discussion while students completed the questionnaire, with the survey taking approximately 20 minutes to complete.

\section{Academic Test}

Students also completed a 25-item famous-artists test consisting of 12 matching phrases, 10 true-false statements and 3 short-answer questions. Specifically, the matching-phrases section required students to match facts or famous paintings to artists (e.g., __ _ cut off part of his ear; __ painted himself in bright clothes and jewels; ___ painted "Women in the Garden"; ___ painted "Sunflowers"). Similarly, students were instructed to respond "True" or "False" to other factual statements about each artist during the second section of the test (e.g., Van Gogh was a preacher before he became a painter; Da Vinci was one of the first artists to paint the mother of Jesus smiling and playing with her baby). The open-ended questions required students to list three artistic styles used by these painters (e.g., brush strokes to provide a sense of movement).

The students were instructed to answer each item and to provide their best guess when they were uncertain about the correct answer. Students were given 60 minutes to complete the test. The primary researcher and another 
educator at the school graded the students' tests, with one point being awarded to each correct response for a total score out of 25 .

\section{Results}

For each dependent measure, a one-way ANOVA was used to analyze students' performance scores with the Tukey-Kramer HSD test for posthoc analyses. When nonparametric statistics were used to analyze students' attitudinal responses, a similar pattern of findings was obtained. In order to establish consistency across the reporting of the dependent measures and because ANOVA procedures are robust to violations of variance (Kirk 1982), only parametric statistics are reported here. Students' mean and standard deviation scores for the famous-artists project, attitudinal questionnaire, and famousartists academic test are listed in Tables 1,2, and 3 respectively as a function of scoring criteria/item type and experimental condition.

\section{Famous-Artists Unit Project}

The total project scores for students in the explicit-training condition were significantly greater than the project scores for students in the implicit-training condition, $F(1,45)=67.05, q=6.00, p<.05$. Specifically, students in the explicit-training condition outscored their peers on five of the six scoring criteria including, answer completeness $F(1,45)=53.03$, answer elaboration $F(1,45)=41.86$, organization $F(1,45)=66.74$, illustrations $F(1,45)=40.76$, and appearance $F(1,45)=52.06$, smallest $q=4.40$, all $p$ s $<.05$. Students scores did not differ on the creativity measure, $F(1,45)=1.69, p>0.5$.

\section{Attitudinal Questionnaire}

Overall, students assigned to the explicit-training condition expressed more favourable attitudes towards cooperative learning than did students in the implicittraining condition, $F(1,45)=5.12, q=1.60, p<.05$. Descriptive analysis of the individual questionnaire items revealed that students in the explicit-training condition consistently provided greater endorsements across all statements in favour of cooperative learning. Furthermore, students in the explicit condition provided statistically greater endorsements for such statements as, "I learn well when working in cooperative groups" $F(1,45)=20.96, q=3.23$, "I stay on task during group work" $F(1,45)=12.12, q=2.50$, and "I accept the contributions of every member of my group" $F(1,45)=4.52, q=1.52$, all $p \mathrm{~s}<.05$. 
Table 1

Famous-Artists Project Means and Standard Deviations as a Function of Scoring Criteria and Experimental Condition

\begin{tabular}{|c|c|c|}
\hline Scoring C riteria & $\begin{array}{c}\text { Explicit-Training } \\
\text { Cooperative Leaming } \\
\text { Condition }\end{array}$ & $\begin{array}{c}\text { Implicit-Training } \\
\text { Cooperative Leaming } \\
\text { Condition }\end{array}$ \\
\hline \multicolumn{3}{|l|}{ A nsw er $C$ ompleteness } \\
\hline M & 4.56 & 3.07 \\
\hline SD & 0.62 & 0.8 \\
\hline \multicolumn{3}{|l|}{ A nsw er E bboration } \\
\hline M & 3.76 & 1.78 \\
\hline SD & 0.89 & 1.17 \\
\hline \multicolumn{3}{|l|}{ C reativity } \\
\hline M & 2.71 & 223 \\
\hline SD & 1.45 & 1.08 \\
\hline \multicolumn{3}{|l|}{ O rganization } \\
\hline M & 4.14 & 2.13 \\
\hline SD & 0.56 & 1.04 \\
\hline \multicolumn{3}{|l|}{ Illustrations } \\
\hline M & 3.37 & 2.65 \\
\hline $\mathrm{SD}$ & 0.43 & 0.33 \\
\hline \multicolumn{3}{|l|}{ A ppearance } \\
\hline M & 3.67 & 2.35 \\
\hline SD & 0.55 & 0.73 \\
\hline \multicolumn{3}{|l|}{ TotalScore } \\
\hline M & 22.11 & 14.02 \\
\hline $\mathrm{SD}$ & 3.1 & 3.48 \\
\hline
\end{tabular}


Two independent reviewers scored students' responses on the openended questions (i.e., What have I learned about cooperative learning? What have I learned about others? What have I learned about myself? and What is the best/worse aspect of cooperative learning?). Specifically, students' responses were scored as either being supportive/positive of cooperative learning or as being unsupportive/negative of cooperative learning. Agreement between the two reviewers was high (97\%), with differences being resolved through discussion.

When asked what they had learned about others, students in the explicit-training condition provided more positive responses than their peers, $F(1,45)=3.94, q=1.38, p<.05$. Examples of positive responses included, "different people have different ideas", "everyone has different feelings and different talents," and "they help you when you are having trouble."

Equally as positive, students in the explicit-training condition provided fewer negative statements across all five open-ended questions than did students in the implicit-training condition $F(1,45)=3.24, q=1.99, F(1,45)=3.14$, $q=1.30$, and $F(1,45)=6.11, q=1.78$, all $p$ s $<.05$. Examples of negative statements provided by students in the implicit condition included, "nothing", "some people don't listen and just talk to others", "people are mean", and "it is hard to work together."

\section{Academic Test}

In general, students performed moderately well on the famous-artists academic test, with students in the explicit-training condition outperforming their peers across each measure of the test. Specifically, students in the explicit-instruction condition obtained greater total scores on the famous-artists unit test than did students in the implicit condition, $F(1,45)=16.41, q=4.05, p<.05$. Separate analyses were completed for each component of the unit test. Explicitly-trained students' matching scores were significantly greater than those of implicitlytrained students, $F(1,45)=35.76, q=5.98, p<.05$. However, students scores on the true/false and fill-in-the-blank portions of the test did not differ as a function of experimental condition, $F(1,45)<45, p>.05$. 
Table 2

Cooperative-Learning Attitudinal Questionnaire Means and Standard Deviations as a Function of Item Type and Experimental Condition

\begin{tabular}{|c|c|c|}
\hline Item Type & $\begin{array}{l}\text { Explicit-Training } \\
\text { Cooperative } \\
\text { Leaming Condition }\end{array}$ & $\begin{array}{c}\text { Im plicit-Training } \\
\text { C ooperative } \\
\text { Leaming C ondition }\end{array}$ \\
\hline 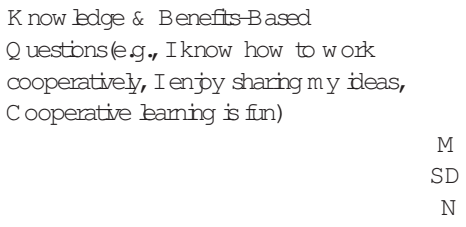 & $\begin{array}{c}44.68 \\
6.99 \\
10\end{array}$ & $\begin{array}{c}41.35 \\
10.70 \\
10\end{array}$ \\
\hline $\begin{array}{l}\text { SocialB ased } Q \text { uestions (e.g., I accept every } \\
\text { m em ber ofm y group, I am not em banrassed } \\
\text { to share ideas, I respond constructively to } \\
\text { others' ileas) } \\
\\
\mathrm{M} \\
\mathrm{SD} \\
\mathrm{N}\end{array}$ & $\begin{array}{c}37.49 \\
9.07 \\
10\end{array}$ & $\begin{array}{c}35.82 \\
11.38 \\
10\end{array}$ \\
\hline Totalscore & $\begin{array}{c}82.17 \\
3.16 \\
20\end{array}$ & $\begin{array}{c}77.17 \\
9.67 \\
20\end{array}$ \\
\hline
\end{tabular}

Table 3

Famous-Artists Academic Test Means and Standard Deviations as a Function of Item Type and Experimental Condition

\begin{tabular}{|r|c|c|}
\hline Test Type & $\begin{array}{c}\text { Explicit-Training } \\
\text { Cooperative } \\
\text { Leaming } \\
\text { Condition }\end{array}$ & $\begin{array}{c}\text { Im plicit-Training } \\
\text { Cooperative } \\
\text { Leaming } \\
\text { Condition }\end{array}$ \\
\hline M atching \\
SD
\end{tabular}




\section{Conclusions and Discussion}

The varying degrees and effectiveness of instructional approaches and teaching techniques continue to be a central topic among researchers and educators (Elliott \& Woloshyn, 1996; Stevens \& Slavin, 1995). Within the past two decades, there has been an upsurge in the use of cooperative-learning practices in the classroom (Antil, et al., 1998; O'Connor \& Jenkins, 1996). Many times, however, students only receive minimal instruction in socially-oriented collaborative concepts and techniques prior to engaging in cooperative activities. While even this "minimal" approach to cooperative learning has been associated with increased academic performance and enhanced social skills, the question arises whether these benefits might be even greater following explicit instruction in critical concepts associated with cooperative learning. Research has clearly documented that students learn best when provided with explicit instruction in such traditional areas as reading and writing (e.g., Butyniec-Thomas, \& Woloshyn, 1997; Gallagher\& Woloshyn, 1999; Harris \& Graham, 1992; Pressley, et al., 1992; Woloshyn \& Elliott, 1998). The results of this study suggest that this may also be the case for cooperative learning. Specifically, providing fourth- and fifth-grade students with explicit training promoted more positive attitudes towards cooperative learning and enhanced their academic performance more than providing them with implicit training.

Students assigned to the explicit-training condition participated in conversations that addressed the overall value of cooperative learning and the specific value of effective communication skills and inclusive practices. The literature suggests that when students participate in such conversations, their communication skills improve, as does the quality of their academic products and related learning. At the same time, social skills improve within the classroom, motivation appears stronger and acceptance and friendliness among peers increases (Ashman \& Gillies, 1997; Battistich, et al., 1993; Lazarowitz, Hertz-Lazarowitz, \& Barid, 1994; Slavin 1990; 1994). It was therefore not surprising that the students in the explicit condition expressed more favourable responses to working cooperatively and rated themselves as more tolerant and accepting of others than did their peers.

Students assigned to the explicit-training condition also demonstrated superior academic gains compared to their peers who received implicit training. This was especially true for test items that required students to recall more obscure information about each artist (i.e., matching task) and is consistent with the overall findings of previous research demonstrating that students' academic 
learning improves as a function of cooperative learning (Antil, et al., 1998; Battistich, et al., 1993; Johnson \& Johnson, 1994; Nastasi \& Clements, 1991; Shachar \& Sharon, 1994).

In this study, completion of the famous-artists project was the one task that most required students to work cooperatively. According to observational field notes kept by the primary researcher, students who received explicit instruction were less likely to engage in non-academic activities (e.g., looking for materials, leaving for the washroom, participating in unrelated conversations) and dysfunctional speech (e.g., criticizing others' ideas, complaining about the task, refusing to contribute) during the class sessions than were their peers. In this study, students in the explicit-training condition were provided with the opportunity to practice the very skills that would most readily contribute to their success on the famous-artist project.

Given the positive findings associated with explicit instruction of process skills related to cooperative learning, the question arises as to why educators do not more readily provide their students with information about these techniques in a direct fashion. That is, why do so few teachers teach explicitly? One simplistic answer is that explicit instruction is somewhat difficult to understand and, in its initial phases, time consuming to implement (Pressley, Goodchild, Fleet, Zajchowski \&Evans, 1989; Woloshyn, Elliott, \& Riordon, 1998). Furthermore, most teachers have not received such instruction as students, nor has such instruction usually been a part of their teacher education. Just as students need repeated instruction and practice in order to acquire effective learning techniques and strategies, teachers typically require extensive in-servicing and ongoing mentoring to become proficient explicit instructors (Duffy, 1993; Woloshyn, et al., 1998). Without such supports, even experienced teachers may be unsuccessful at implementing explicit instruction (El-Dinary \& Schuder, 1993). Thus, we strongly encourage those involved in the delivery and implementation of teacher education programs to include explicit instruction as part of teachers' professional development. In this context, beginning and aspiring teachers need to understand the differences between explicit and implicit instruction. Furthermore, teacher educators need to provide them with opportunities to engage and reflect upon this process as it relates to the teaching of critical skills including cooperative learning.

Undeniably, the processes of explicit instruction and cooperative learning require commitment from both teachers and students. First, teachers must devote personal time to learning how to provide explicit instruction as part of cooperative learning. Second, they must be prepared to devote substantial class time to this process in order to provide students with multiple opportunities to acquire repertoires of effective learning and study skills. We 
believe that ultimately the personal satisfaction and realization that they are providing students with the necessary skills to become capable, independent learners in the $21^{\text {st }}$ century will outweigh teachers' initial reservations about time and effort when teaching cooperative learning explicitly.

\section{Acknowledgements}

This research was partially supported by a grant to Vera Woloshyn from the Social Sciences and Research Council.

\section{References}

Antil, L.R., Jenkins, J.R., Wayne, S.K., \& Vadasy, P.F. (1998). Cooperative learning: Prevalence, conceptualisations and the relation between research and practice. American Educational Research Journal, 35, 419-454.

Ashman A.F., \& Gillies, R. M. (1997). Children's cooperative behavior and interactions in trained and untrained groups in regular classrooms. Journal of School Psychology, 35, 261-279.

Battistich, V., Solomon, D., \& Delucchi, K. (1993). Processes and student outcomes in cooperative learning groups. The Elementary School Journal, 94, 19-32.

Berg, K. (1993, April). Structured cooperative learning and achievement in high school mathematics class. Paper presented at the American Educational Research Association (AERA), Atlanta, GA.

Blumfield, P.C., Marx, R.W., Soloway, E., \& Krajcik, J.S. (1996). Learning with peers: From small group cooperation to collaborative communities. Educational Researcher, 25, 37-40.

Butyniec-Thomas, J., \& Woloshyn, V.E. (1997). The effects of explicit-strategy instruction and whole-language instruction on students' spelling ability. Journal of Experimental Education, 65, 293-302.

Duffy, G.G. (1993). Rethinking strategy instruction: Four teachers' development and their low achievers' understandings. Elementary School Journal, 93, 231-247.

El-Dinary, P., \& Schuder, T. (1993). Seven teachers' acceptance of transactional strategies instruction during their first year using it. Elementary School Journal, 94, 207-219. 
Elliott, A., \& Woloshyn, V.E. (1996). Using collaborative learning strategies in the classroom: Overcoming teacher resistance. The Canadian School Executive, 15, 3-9.

Gallagher, T., \& Woloshyn, V.E. (1999). Comparing explicit multiple-spelling strategy instruction with traditional language arts instruction in eighthgrade students. Brock Education, 8, 36-46.

Harris, K.R., \& Graham, S. (1992). Helping young writers master the craft: Strategy instruction and self-regulation in the writing process. Cambridge, MA: Brookline Books.

Johnson, D.W., \& Johnson, R.T. (1990). What is cooperative learning? In M. Brubacher, R. Payne, \& K. Rickett, (Eds), Perspectives for small group learning (pp. 68-80). Oakville, ON: Rubicon Publishing Inc.

Johnson, D.W., \& Johnson, R.T. (1991). Classroom instruction and cooperative learning. In H. Waxman, \& H. Walberg, (Eds), Effective teaching: Current research (pp. 277-294). Berkeley, CA: McCutchan Publishing Company.

Johnson, D.W., \& Johnson, R.T. (1994). Learning together and alone: Cooperative, competitive, and individualistic learning ( $4^{\text {th }} \mathrm{ed}$.). Boston: Allyn \& Bacon.

Kagan, S. (1990a). Cooperative learning for students limited language proficiency. In M. Brubacher, R. Payne, \& K. Rickett, (Eds), Perspectives for small group learning (pp. 202-223). Oakville, ON: Rubicon Publishing Inc.

Kagan, S. (1990b). The structural approach to cooperative learning. Educational Leadership, 47, 12-15.

Kahl, B., \& Woloshyn, V.E., (1994). Using elaborative interrogation in cooperative learning settings: One good strategy deserves another. Applied Cognitive Psychology, 8, 465-478.

Kirk, R. (1982). Experimental design (2 ${ }^{\text {nd }}$ Ed.). Belmont, CA: Brooks/Cole.

Lazarowitz, R., Hertz-Lazarowitz, R., \& Barid, J.H. (1994). Learning science in a cooperative setting: Academic achievement and affective outcomes. Journal of Research in Science Teaching, 31, 1121-1131.

Meloth, M. S., \& Deering, P. D. (1992). Effects of cooperative conditions on peer-group discussions, reading comprehension, and metacognition. Contemporary Educational Psychology, 17, 175-193.

Meloth, M.S., \& Deering, P. D. (1994). Task talk and task awareness under different cooperative learning conditions. American Educational Research Journal, 31, 138-165.

Nastasi, B., \& Clements, D. (1991). Research on cooperative learning: Implications for practice. School Psychology Review, 20, 110-131. 
O’Connor, R.E., \& Jenkins, J.R. (1996). Cooperative learning as an inclusion strategy: A closer look. Exceptionality, 6, 29-51.

Pressley, M., El-Dinary, P.B., Gaskins, I., Schuder, T., Bergman, J.L., Almasi, J., \& Brown, R. (1992). Beyond direct explanation: Transactional instruction of reading comprehension strategies. Elementary School Journal, 92, 513-555.

Pressley, M., Goodchild, F., Fleet, J., Zajchowski, R., \& Evans, E.D. (1989). The challenges of classroom strategy instruction. Elementary School Journal, 89, 301-342.

Shachar, H., \& Sharon, S. (1994). Talking, relating, and achieving: Effects of cooperative learning circles. Instructional Science, 19, 445-466.

Sharon, S. (1994). Handbook of cooperative learning methods. Connecticut: Greenwood Press.

Slavin, R. E. (1990). Cooperative learning: Theory, research and practice. New Jersey: Prentice-Hall, Inc.

Slavin, R.E. (1994). Collaborative learning: Theory, research and practice (2 $2^{\text {nd }}$ ed.). Boston, MA: Allyn \& Bacon.

Slavin, R. E. (1995). Cooperative learning. Boston: Allyn \& Bacon.

Stevens, R. J., \& Slavin, R.E. (1995). The cooperative elementary school: Effects on students' achievement, attitude and social relationships. American Educational Research Journal, 32, 321-351.

Thousand, J. S., Villa, R. A., \& Nevin, A. I. (1994). Creativity and collaborative learning. Baltimore: Paul H. Brooks Publishing Co.

Woloshyn, V. E., \& Elliott, A. (1998). Providing seventh-and eighth-grade students with reading and writing strategy instruction: Comparing explicit-strategy and implicit-strategy programs. The Reading Professor, 20, 59-79.

Woloshyn, V. E., Elliott, A., \& Riordon, M. (1998). Seven teachers' experiences using explicit strategy instruction in the classroom. Journal of Professional Studies, 5, 18-28. 
Promoting Cooperative Learning in the Classroom

\section{Appendix A}

\section{Claude Monet}

Claude Monet was born in Paris, France, in 1840. When he was young he moved to a town right by the sea where ships from all over the world would stop to pick up supplies. Monet's father owned a grocery store that sold supplies to the sailors and shipping companies. Monet did not do very well in school. He had a very good sense of humour and spent most of his time drawing funny pictures. Monet made money by selling these drawings and eventually tried painting.

Monet tried the idea of painting outdoors and he loved it. Many of Monet's paintings are of boats, oceans, ponds, and lakes. Monet even fixed up a boat as a floating studio. He sailed up and down rivers stopping to paint whatever he liked.

The Salon was a place in Paris where people came from all over the world to see famous artists' paintings. Monet entered his paintings often. Some were accepted and some were not. "Women in the Garden" was one of Monet's paintings that didn't make it into the Salon gallery. In this painting Monet used his favourite model, Camille, for all four women in the painting. Monet and Camille got married and had a son named Jean.

Monet helped invent an important style of painting called impressionism. This style of painting usually showed scenes of everyday life and nature, where the colours, shadows, and lights in the paintings are as real as possible, such as the paintings titled "The Cliff Walk Pourville", "The Japanese Footbridge", and "Haystacks." The exciting brush strokes and colours in Monet's paintings give you the feeling of being right there at the moment he made the painting.

Claude Monet lived to be 86 years old. He spent his last ten years painting scenes of his water garden, such as "Water Lilies." When Monet was older, people finally began to appreciate his now famous paintings. 


\title{
"The Report Card is Pretty Ugly": Children's Perspectives of Assessment
}

\author{
J. Karen Reynolds \\ Sonya Corbin Dwyer \\ University of Regina
}

\begin{abstract}
Teacher education research attention has focused on the professional development of teachers. What is often neglected in this landscape of research is students' experiences with learning. This paper describes children's perceptions of classroom assessment practices. We draw from Bourdieu's (1990) theory of capital to interpret students' comments regarding practices associated with tests, collaborative assessment and evaluation, and grades. Bourdieu (1986) suggests that various forms of capital (cultural, social, and symbolic) mediate human activity. Within this context, these assessment practices are means by which institutionalized cultural capital, in the form of high grades, are generated for exchange on competitive home and school markets.
\end{abstract}

Reflection on how social phenomena get defined as problems in need of explanation in the first place quickly reveals that there is no such thing as a problem without a person (or group of them) who have this problem: a problem is always a problem for someone or other. (Harding, 1987, p. 6)

Assessment is socially situated in unequal relations of power among people engaged in purposeful activity. A more democratic approach to assessment would involve more equitable relations of power among teachers, students, parents, administration, policy-makers, and researchers. Greater communication and collaboration within, and across, interest groups will facilitate common understandings regarding what counts as useful assessment policy and fair assessment practices. This article explores children's

Karen Reynolds is an Assistant Professor of Professional Studies. Her research interests include social constructivism and the experience of marginalized people. Sonya Corbin Dwyer is an Associate Professor of Educational Psychology. She teaches a course Assessing Student Learning to pre-service teachers. Both are with the Faculty of Education at the University of Regina. 
perceptions of assessment practices in an attempt to further educators' awareness of children's needs.

This article is part of a larger study which examined the particular contexts for classroom practices associated with assessment and evaluation (Reynolds, 1997). Children were chosen as the topic for this paper because children are the closest to the phenomena and are the primary beneficiaries of any related costs and benefits. In this paper, they are represented and interpreted as subjects, not objects, through stories of their experience of assessment.

Assessment and evaluation involve different processes:

Assessment is the systematic process of gathering information about student learning, what they know, are able to do, and are trying to do. Evaluation (is) the process of making judgments and decisions based on the interpretation of evidence of student learning gathered throughout assessment. Evaluation might be done by the teacher or the student independently or in collaboration. (British Columbia Ministry of Education, 1994, p. 21)

For the purposes of this paper, 'assessment' is used to include assessment and evaluation processes.

\section{The Social Construction of Assessment}

Before describing the study, it is important to discuss constructivism because the children, unlike the teacher, have never had any formal training in assessment. Yet, they had skills in this technical area. They saw criterionreferenced evaluation activities as occasions when their teacher involved them in setting performance criteria. From these activities, the children learned that they received higher marks when they understood how their teacher marked their work. Children also belong to a community of learners by learning with and from each other through observation and discussion of assessment practices. Children increased their access to high marks by negotiating performance criteria with their teacher. Within this context, they clarified their teacher's interpretation of criteria, changed criteria, and even rejected her interpretations. So how did the children 'obtain' this knowledge? This question is seldom asked by educators or researchers. Why not?

Harding (1993) cautions researchers that some socially situated locations, such as people from socio-economically oppressed groups, are more 
objective starting points for inquiry than others. Furthermore, researchers who examine policy from a privileged position, without interrogating the position itself, severely limit their access to critical understanding of issues and problems.

Knowledge claims are always socially situated, and the failure by dominant groups...to interrogate their advantaged social situation and the effect of such advantages on their beliefs leaves their social situation a scientifically and epistemologically advantaged one for generating knowledge....So one's social situation enables and sets limits on what one can know; some social situations - critically unexamined dominant ones - are more limiting than others in this respect, and what makes these situations more limiting is their inability to generate the most critical questions about received belief. (Harding, 1993, p. 54 - 55)

Like Harding (1993), Gaskell (1988) sees a need for policy research that addresses concerns of groups that are under-represented or absent in political debate. Gaskell points out that issues are clarified and new questions generated for consideration in the political process when research begins from the standpoints of interest groups. She contends that democratic policy research explores issues from multiple and even conflicting standpoints:

Researchers can explore issues from many potentially conflicting points of view including that of the student, the parent, the teachers' federation, or the government agency, to mention only a few. It can clarify, legitimate, and expand the political agendas these groups start with instead of simply solving problems for them..... One role of a controversial study is to highlight issues of concern to children and introduce them into the debate. (Gaskell, 1988, p. 413 - 414)

What does this have to do with assessment? Moss (1996) addresses assessment in terms of educational measurement. Within this context, she contends that collaborative inquiry has been absent from traditional measurement research. Moss adds that developers have traditionally created interpretations of assessment for the people who use them; a top-down approach to assessment that excludes people from constructing and even challenging interpretations that directly affect their lives. 
Those who are assessed or who use the assessment information often have no ready access to reconstruct or challenge these characterizations that may have an impact on their lives (Moss, 1996, p. 24).

Darling-Hammond (1996), Gaskell (1988), Harding (1993), and Moss (1996) favour studies of how meaning is produced and received within and across contexts. Moss points out that interpretations of assessment policy and related practices have serious political consequences in terms of who speaks for whom, and whose interests are represented.

Delandshere and Petrosky (1994) paint a picture of evaluative judgements regarding student progress as discourse in terms of who has the power to decide what counts as knowledge. They propose that people's interpretations of assessment information are shaped by values of a particular discourse regarding what counts as knowledge.

Moss (1996) suggests that interpretivist research traditions allow researchers to comprehend their own, and others', constructed meaning within and across contexts in which meaning is created and received. Because interpretivist traditions assume that meaning is intersubjective, meaning must be understood from the standpoints of people affected. Moss explains that the course and form that interpretation takes will depend on the dynamics of a context.

Like Harding (1993) and Hawkesworth (1989), Moss (1996) argues that there are no uncontested bases for establishing knowledge claims. Interpretations mediate, and are mediated by, the politics of knowledge production in specific contexts. She points out that research traditions differ in the ways in which they address the limitations of scientific inquiry.

In this section, important questions regarding power and representation in relation to assessment-evaluation were raised. Moreover, issues associated with who has the power to define and legitimate what counts as knowledge in interpretations of assessment-evaluation, and whose interests are represented by interpretations of assessment-evaluation, are presented as the heart of the debate. Therefore, the purpose of this study is to examine children's perspectives of classroom assessment.

\section{Methods of Data Collection and Ongoing Analysis}

Ethnographic techniques were used to collect and analyze information regarding children's perspectives of classroom assessment practices. Specifically, information was gathered from students using formal and informal observations (the children's involvement in classroom assessment activities), semi-structured 
interviews (questions included their opinions of different types of assessment activities, and of marks and grades), and field-notes.

Data analysis involved content analysis and triangulation. Content analysis of the multiple sources identified recurring words, ideas, images, and themes. Data were triangulated along intersecting axes of method, time, and space. Constant comparative analysis and methodological triangulation corroborated multiple sources associated with themes and categories.

\section{Participant-Observation}

A collaborative approach framed the researcher's role as a participant-observer in the classroom. From past experiences as a teacher, it was assumed that credibility and establishing trust with the grade 5/6 students depended upon being useful in the classroom. It was decided that this would begin by marking students' assignments, preparing materials for science and art classes, and supervising computer and library classes. Remedial assistance was also provided to several grade six students who were experiencing difficulty with computation. To increase the researcher's perceived credibility, the researcher proposed an activity developed for teaching research skills with children (Reynolds, 1990). As a result, students' experiences with observations helped them to understand why the researcher occasionally observed and made notes during class time.

\section{The Participants}

The group of students whose parents gave consent for their participation included 11 female students and 13 male students in a grade 5/6 split classroom in an elementary school located in a middle class neighbourhood of a large urban centre. Each student was individually interviewed once. These interviews were audio-taped and later transcribed. One hundred and two informal and formal observations took place over a six-month period. Ninety of these observations were informal, or reconstructed. Twelve of these observations were formal, or immediate.

\section{Children's Perceptions}

\section{“The big picture isn't always the important picture" (David)}

Students' interpretations of classroom assessment practices, and their reasons for holding such views, were explored. Students described how and why they 
would change certain practices. Equally important were students' interpretations of how marks, structured written comments, and letter grades affected their intra- and inter-personal relationships.

\section{Tests}

Students in the study liked tests when they received high marks and did not like them when they received low marks. Children associated stress and anxiety with tests, whether or not they did well. For example, David (a pseudonym) described a test as "a big nerve-wracking thing" even when he knew that he would do well. For Jeremy, a test served the sole purpose of generating marks for conversion to letter grades. He personified tests by saying that a test made up a letter grade: "A test is you have to prove how good you are to get a letter grade. It is an important part of your grade, it makes up your grade." Bob thought that low test marks led to low letter grades. He explained "if you get bad marks on your tests that will reflect on your report card."

Students associated stress and anxiety with tests because they had limited prior knowledge of specific content. In contrast, they liked pre-tests because they knew what to study for a final test. Within this context, they had more control over an activity and received higher marks. Jeremy: "If you're really bad at it and then you take a pre-test and find out what you need to work on, then you correct it, and you could get it right on the test." Martin: "Pre-tests help me a lot because then I can find out what kind of stuff I will have to do, and what kind of stuff I don't have to do. So I can study that right thing and then I can do pretty well on it." Meghan said that she was frightened by test schedules that did not allow her sufficient time to study. "When the teacher says, 'Okay we're having a test on math,' it's just shocking and then you just get scared. Like when it's a test you think, 'Oh no, what if I get a bad mark and then it's recorded and everything."'

Matt said that he did not receive good marks on tests because tests made him nervous. He described how he experienced memory loss, increased heart rate, and tremors: "I do badly on tests because I just get really nervous. When I'm doing my regular work I normally get perfect. It bothers me that when I'm doing tests I get ten wrong. Tests are not harder and they're not easier. They're just like regular work but I get nervous. I don't think I get nervous but I am.”

R: What are some of the things you feel when you're nervous?

Matt: Boom, boom, boom! (says while hitting chest). 
R: Your heart?

Matt: Yeah. My hands start to shake while I'm writing, my knees are shaking like a motor (makes sound of a motor). I'm just trying to be calm and I'm always like, 'Oh, what is this!' And I know it's like, ' $8+6$, Oh-Oh-Oh! What is it! I can't remember! I can't remember! Oh, 14!' Finally, after that long!

Like Matt, Summer and Bob commented that they experienced memory loss before a test. Rick explained that he was nervous before tests because he might not be able to do the questions, and low test marks could result in poor letter grades on his report card.

David argued that teachers did not need to test him to determine what he knew. He thought that his daily work should be sufficient evidence of this. He pointed out that tests had limited value because they created stress, and did not necessarily reinforce important information and skills.

I don't think I should be tested. The work I've done should show it. It's necessary to be taught. It's not necessary to get worried about what you've been taught, and to quickly sweat a lot or just write a lot at about what you've been taught. No matter what, in twenty years I'll probably forget the things that aren't, won't, be important to me. So you remember what's important always and you don't remember what's not. So no matter what's on the test you're still only going to remember what you think you need to remember. You remember what you like, you remember what you need to know.

David saw test anxiety as an unnecessary expenditure of his energy.

\section{Collaborative Assessment and Evaluation}

Students liked activities that involved means for increasing their access to high grades. They learned that they received high grades when they understood how the teacher assessed and evaluated their work. Within this context, children improved their access to high grades by collaborating with the teacher and peers to identify and define assessment and evaluation criteria for an activity. 
Negotiation strategies ranged from clarification of criteria to changing, and even rejecting, criteria.

Students focused primarily on evaluative criteria because they thought that this criteria generated grades and in particular, high grades. In the following excerpts, students explain why they liked activities involving collaborative assessment and evaluation.

Jeremy: If you cover every single one of those criteria you'll get a good mark.

Martin: I can find out what I need to do to get a higher mark.

Casey: If you see criteria before, you know what you're going to be marked on so you know what you have to work on.

Meghan: I like having the criteria saying what you need to do to get a 4 [the highest score].

Matt: You know what you have to do to get a certain mark.

Tricia: You know what you're getting marked on.

Meghan: You know what you need to get an A.

Oscar thought that even though criteria guided his learning, criteria also represented marks. He assumed that he would get a higher grade by adhering to assessment and evaluation criteria: "I know exactly what to do. Like if it says 'put some metaphors and similes in the story.' I'll put some in." Meghan pointed out that rigidly set criteria limited her learning. She explained that knowing grading criteria "improves on what they're telling you to do, but not does not improve on what else isn't in the criteria."

\section{Grades}

Through lived experience, children learned that high marks and grades could be exchanged for money, food and clothing, increased self-esteem, positive relationships with teachers and parents, membership in the peer group, and access to further education. Therefore, they wanted increased access to high marks and grades. In the following excerpts, Brett, Matt, Summer, and Buffy 
describe the exchange value of marks and grades in terms of educational and career opportunities.

Brett: I just know I need an education to do the things that I would like to do. I'd like to be maybe a marine biologist.

Matt: The report cards help to get you into a good university. That education will help you get a job, just like being an accountant or a lawyer.

Summer: When you want to go to like a good school or a university or something you have to have good marks to get into it. If you get good marks you get a good job when you grow up.

Buffy: The report card tells me the marks that I got and if I could try harder. So it tells me if I'm not doing well in school or if I am. Later on in life I might want to go into medicine, or I might want to go into acting and drama or sports.

While these children thought that good marks guaranteed access to good universities, which led to professional employment, students were also concerned with the power of letter grades in affecting relationships. Jeremy explained that letter grades influenced the degree of respect shown to children by teachers, parents, and peers: "If you get good marks then people take you more seriously and encourage you. They treat you with respect. If you got a D, everybody's going to say you could have done way better than that. If you got an A they say "congratulations." R: "Who would treat you better?" J: "Teachers sometimes...friends and parents."

David commented that parents might label a child as capable or incapable based upon letter grades on a report card. Moreover, parents might become very upset with a child if s/he received low grades. David concluded that letter grades were potentially damaging to a child's self-esteem and relationships with parents: "If you don't get an A for your ability then your parents are going to think that you don't have an ability. They'll think you're doing terrible cause this is what you've gotten. They're very upset with you and that makes you feel terrible because you've worked so hard for what you've done." Greg commented that when he did well on his report card he was praised by his parents. Meghan, Martin, and Matt recalled that their parents rewarded high letter grades with food, clothing, CDs, and school supplies. 
Meghan: If I get a good report card they'll take me out to dinner, or this term my mom bought me shirt.

Martin: I am rewarded only if I get two or three A's. Then I get some useless stuff like pencils and erasers.

Matt: I know some people, they get a CD for every A they get. Every time I get an A I get to choose what kind of dinner we're going to have.

Rick (Gr.6) said that his parents told him he would be allowed to quit a privately funded math tutoring class he attended if he received straight As on his report card, with the exception of Physical Education. He recalled receiving $\$ 50$ for a report card of straight As when he was in grade 5. Rick said that he liked receiving rewards for letter grades depending on what he could get. Students knew that low letter grades brought few rewards. Summer explained that she did not receive a reward for her grade 6 report cards because she did not do well enough. She recalled the time in grade 5 when she received a $\mathrm{C}+$ on her report card and her parents took her out for dinner. Summer commented that she no longer cared if her family did not celebrate her report card.

Martin described his feelings of isolation when he received a low letter grade: "I like letter grades but I don't like it when I get too low ones. I feel like the only person in the class who's not doing that well in that subject. It makes me feel like I'm all by myself down low and everybody else us up high."

According to David, a student's relationship with a teacher often influenced the marks that s/he received: "If the teacher likes the student then the student's going to get better marks, but if the teacher doesn't like the student's style, just the student himself, then that's going to affect big time on the marks. If the teacher likes you, you might not get a better mark but you'll get a more deserving mark, might get a better mark. If the teacher doesn't like you, you'll probably get a less deserving mark. A teacher needs to like you if you want to do well."

Several students explained that letter grades affected identity and selfesteem. Casey said that she learned more about herself with each report card: "The report card tells you what kind of person you are, and it also tells yourself who you are. It tells you more about yourself every time you get one."

Matt demonstrated he was more independent in his self-perception although he felt the report card reflected teachers' perceptions of him as an individual: "The report card is actually the teacher's opinion of me but I have my opinion of me. I think I'm a pretty bright kid." 
David was convinced that letter grades should neither guide his reasons for learning nor shape his identity:

You should tell you who you are and you should know who you are, not what the little letters on this little sheet of paper say. Those shouldn't say anything 'cause if I drew a shape that looks like an A rather than a shape that looks like an F, that's just a drawing, just a little thing on a sheet of paper. I think that the report card is pretty ugly. It's not one of my favourite pictures. I wouldn't buy it for a million dollars if it were in some museum. It's sort of a false goal. It should be to work well should be your goal, not getting As.

David argued against a view of education wherein learning was exchanged for grades and his identity.

\section{The Assessment Landscape}

Students also liked having opportunities to talk about their opinions and concerns. For some students it may have been the first time that their views had been taken seriously by an adult. Other students had dialogued with parents and adults from a very young age. One girl in grade 6 told me that she liked being able to talk about things that bothered her without fear of recrimination.

Children in the study were the objects of assessment and evaluation policy. They were the ones being graded, and they were very clear about this. Grades were key stakes in their lives. Students saw tests and activities involving collaborative assessment and evaluation as means by which grades were generated for exchange on competitive home and school markets. The system exists for students to 'trade' grades for peer group acceptance, approval, praise, prestige, money, clothing, food, and compact discs and so they did.

They saw themselves not only in competition with peers for grades and identity, but also in competition with teachers' and parents' expectations regarding their achievement.

\section{Grades as Capital}

Bourdieu's (1986; 1990) concept of "capital" as a theoretical framework was used to examine the children's stories about their experiences with classroom assessment. Within this context, assessment and evaluation policies and practices represented purposeful activity situated within unequal relations of 
power among students and teachers. Bourdieu is particularly interested in the forces that shape the means by which capital or power is produced, distributed, and exchanged in a field. Within this context, assessment practices generate institutionalised cultural capital in the forms of grades with high exchange value on home, educational, and employment markets.

Bourdieu (1990) explained that interconnections among people's actions and objectives can be understood by focusing on how people use 'artifacts' and conventions as a means to compete for capital or power in competitive fields. Various forms of capital mediate human activity. In the classroom, these students viewed 'marks' or grades as capital. So perhaps a leap can be made that for some people, capital becomes their motivation. They work toward producing one type of capital to exchange for another type.

Ambiguity and risk were also key components of the students' interpretations of classroom assessment and evaluation practices. Students focused on reducing ambiguity of evaluative criteria to lessen risk of failure. In this way, positive effects that ambiguity might have on learning were weakened.

When students learned that marks and grades were mediated by evaluative criteria, they wanted more control over criteria. Many students reasoned that by collaborating with the teacher and their classmates to set evaluative criteria, they increased their access to high grades. They knew what to do to get a high grade. It appeared that students' interests to exercise control over evaluative criteria were desires for control over the authority of assessment and evaluation practices to mediate access to achievement. It was not surprising that students wanted more control over criteria that affected quality of life.

Students' comments as interpreted by Bourdieu's theory of capital helped to illustrate that competitive school and home economies taught children to exchange their learning for grades, and even equate learning with grades. Students wanted high grades because they thought that high grades had high exchange value on reward markets. In this way, high grades were an important form of capital or currency.

This discussion of 'grades as capital' extends the concept of one of the functions of assessment being gatekeeping "in which assessment determines who is granted a privilege such as admission or graduation" (Nagy, 2000, p. 262). How does 'grades as capital' fit with equal opportunity, especially equal opportunity to learn? "Assessment practices and policies should be regularly reviewed with the goal of improving the learning environment through effective evaluation techniques" (Taylor, 2001, p. 4). A greater understanding of the purposes of assessment is needed to guide practice (Taylor), and not only the 
purposes of assessment from the school district's point of view but the purposes from the children's perspectives.

\section{Issues for Consideration}

The biggest issue to consider is where 'grades' reflect student achievement. While it is beyond the scope of this paper to explore this topic, the children's comments certainly illustrate that they do not feel they do. If they feel grades are 'artificial' because they are influenced by whether or not they are liked by the teacher, for example, what are the implications of these beliefs on their learning? How will educators better gather information needed to report on student achievement? It is important to consider the information needed by different parties, such as parents and teachers whose information needs are different (Roeber, 2002).

Assessment formats are another issue that was raised by the children. From their stories of the stress caused by tests, are these the most appropriate methods of gathering information? While more educators are using authentic assessment approaches, testing is still widely used (Roeber, 2002). At the very least, it appears that test-taking strategies (particularly relaxation methods) should be taught in the early grades.

From this examination of children's perspectives, it appears that most students wanted to maximize their access to success. From a young age, they learned that grades affected the quality of their lives in positive and negative ways. Not surprisingly, they sought to reduce negative consequences and increase positive effects. Within this context, it is recommended more collaborative case studies be conducted to further extend educators' awareness of what assessment approaches 'work' and what one 'hurt' from children's perspectives.

\section{References}

Bourdieu, P. (1986). The forms of capital. In J. G. Richardson (Ed.), Handbook of theory and research for the sociology of education (pp. 241-258). New York: Greenwood Press.

Bourdieu, P. (1990). The logic of practice. Cambridge: Polity Press.

British Columbia Ministry of Education (1994, February). Assessment handbook series: Student-led conferences, portfolio assessment, student self-assessment, performance assessment (XX0246). Victoria: Author. 
Darling-Hammond, L. (1996). The right to learn and the advancement of teaching: Research, policy, and practice for democratic education. Educational Researcher, 25(6), 5-17.

Delandshere, G., \& Petrosky, A. (1994). Capturing teachers' knowledge: Performance assessment a) and post-structuralist epistemology b) from post-structuralist perspective c) and post-structuralism d) none of the above. Educational Researcher, 23(5), 11-18.

Gaskell, J. (1988). Policy research and politics. The Alberta Journal of Educational Research, 34(4), 403-417.

Harding, S. (Ed.) (1987). Feminism and methodology. Bloomington: Indiana University Press.

Harding, S. (1993). Rethinking standpoint epistemology: What is 'strong objectivity'? In L. Alcoff \& E. Potter (Eds.), Feminist epistemologies (pp. 49-82). London: Routledge.

Hawkesworth, M. E. (1989). Knowers, knowing, and known: Feminist theory and claims of truth. Signs: Journal of Women in Culture and Society, 14(31), 1-25.

Moss, P. A. (1996). Enlarging the dialogue in educational measurement: Voices from interpretative research traditions. Educational Researcher, 25(1), 20-28.

Nagy, P. (2000). The three roles of assessment: Gatekeeping, accountability, and instructional diagnosis. Canadian Journal of Education, 25(4), 262-279.

Reynolds, K. (1990). You can research: A systematic and organizational model for children. Author: Thunder Bay, Ontario.

Reynolds, K. (1997). Criterion-referenced assessment and evaluation as socially situated practice. Unpublished doctoral dissertation, University of British Columbia, Vancouver, BC, Canada.

Roeber, E. (2002). How will we gather the data we need to inform policy makers? In R. Lissitz \& W. Schafer (Eds.), Assessment in educational reform: Both means and ends (pp. 162-191). Toronto: Allyn \& Bacon.

Taylor, A. R. (2001). Policy watch: Student assessment. Education Analyst, 4(3), 4-5. 


\title{
Le sentiment d'incompétence pédagogique des enseignants en début de carrière et le soutien à l'insertion professionnelle
}

\author{
Stéphane Martineau \\ Annie Presseau \\ Université du Québec àTrois-Rivières
}

\begin{abstract}
Résumé
Ce texte présente le résultats de deux recherches exploratoires menées auprès de treize enseignants débutant dans la carrière et de six directeurs d'établissements scolaires $d u$ niveau secondaire. Nous y démontrons que le sentiment d'incompétence pédagogique vécu par les nouveaux enseignants s'explique à la fois par les logiques dans lesquelles s'inscrivent leurs actions et par un certain nombre de phénomènes de systèmes propre au monde scolaire.
\end{abstract}

\section{Introduction}

Les premières années dans une carrière sont cruciales pour quiconque. Cela est d'autant plus vrai pour la profession enseignante. On qualifie souvent l'entrée dans la carrière de «période de survie ». Le « choc de la réalité » s'accompagne généralement de la sensation d'être vulnérable. Durant leurs premières années, de nombreux enseignants éprouvent de multiples difficultés dans leur quête d'accomplissement professionnel. Ce court texte rend compte des résultats de deux recherches exploratoires menées entre 1999 et 2001. Dans la première, l'objectif général était d'exposer la nature et les caractéristiques du sentiment d'incompétence ressenti par les enseignants nouvellement en exercice dans les écoles secondaires québécoises. Dans la deuxième, nous avons recueilli le point de vue de quelques directeurs d'école.

Stéphane Martineau, Ph.D.- Professor, Départment des sciences de l'éducation, Université du Québec à Trois-Rivières (UQTR), Centre de recherche interuniversitaire sur la formation et la profession enseignante (CRIFPE). Annie Presseau, Ph.D. -

Professeure, Départment des sciences de l'éducation, Université du Québec à Trois-

Rivières (UQTR), Centre de recherche interuniversitaire sur la formation et la profession ensignnante CRIFPE). 
Le sentiment d'incompétence pédagogique

\section{Cadre de référence}

\section{Sur l'insertion professionnelle}

L'enseignant qui débute dans la carrière se trouve devant un double défi. D'abord, il doit réaliser son insertion sur le plan institutionnel. Ensuite, il doit ajuster ou développer rapidement plusieurs savoirs (Tardif \& Lessard, 1999) et plusieurs compétences à la situation concrète d'intervention où il se trouve. Ainsi, tout en apprenant à connaître son lieu de travail et ses collègues, il continue à apprendre son métier. Ce double défi peut facilement le conduire à adopter un comportement traditionnel et peu novateur, en d'autres termes l'amener à se soumettre à la pression de conformité venant du milieu de travail (ce qui, il faut l'avouer, n'est pas obligatoirement une mauvaise chose, la capacité et la volonté d'innovation venant plus tard).

Les recherches portant sur la socialisation professionnelle des enseignants démontrent que l'entrée dans la carrière est une étape déterminante (Zeichner \& Gore, 1990). Le débutant doit se construire une représentation adéquate et fonctionnelle de son environnement de travail et ce, non plus à partir du point de vue d'un élève (qu'il a été) mais à partir de celui d'un enseignant (qu'il est maintenant). En ce sens, l'insertion professionnelle est un véritable processus de transformation identitaire (Martineau \& Corriveau, 2000). Dans ce processus, il n'est pas rare que le nouvel enseignant se sente bousculé dans ses croyances construites depuis son entrée à l'école jusqu'à sa sortie de l'université (Wideen, Mayer-Smith, \& Moon, 1998). Persuadé de pouvoir s'adapter rapidement à son nouvel emploi, il « déchante » souvent très rapidement.

Les premières années dans la profession exercent ainsi une influence considérable sur la suite de la carrière. Dans les cas les plus dramatiques, des débuts difficiles peuvent conduire le nouvel enseignant à abandonner complètement l'enseignement. À l'inverse, oeuvrer dans un contexte de travail agréable et stimulant accroît très souvent le désir d'engagement professionnel. «Les débuts dans l'enseignement jettent les bases de la dynamique motivationnelle qui animera l'enseignant» (Raymond, 2001, p. 23). Par ailleurs, les premières expériences de travail en milieu scolaire fournissent une large part des matériaux qui constituent la base de connaissances pédagogiques personnelles. En ce sens, la période d'insertion au travail n'est pas sans exercer une influence sur le développement professionnel ultérieur du praticien (Huberman, 1989). Ajoutons à cela que cette période de la carrière se fait la plupart du temps, en Amérique du Nord à tout le moins, sous le sceau d'une 
précarité d'emploi qui peut parfois se prolonger pendant plusieurs années (Mukamurera, 1999). Cette situation n'est pas sans entraîner plusieurs désagréments: multiples préparations de cours différents; prise en charge de classes dans divers niveaux; contrat signé à la dernière minute laissant peu de temps pour se préparer; multiples changements de lieu de travail, etc. Dans ces conditions la constitution de la base de connaissances pédagogiques personnelles devient plus ardue. Par exemple, chaque nouveau contrat peut être l'occasion d'un recommencement « à neuf » où le débutant vit plus profondément que l'enseignant régulier la remise en cause de ses connaissances et de ses compétences. Pas étonnant que, dans ces conditions, de trop nombreux enseignants à l'aube de leur carrière se sentent littéralement dépassés par la tâche à accomplir.

\section{Sur le sentiment d'incompétence pédagogique}

Le débat actuel sur la professionnalisation de l'enseignement pose, entre autres, que l'enseignant possède une certaine autonomie professionnelle (malgré l'imposition des programmes scolaires) et dispose de compétences pédagogiques (Gauthier, Desbiens, Malo, Martineau, \& Simard, 1997). Cette autonomie et ces compétences doivent dans la pratique être mobilisées afin de produire un effet sur les apprentissages et la socialisation des élèves: l'effet enseignant (Felouzis, 1997). Par conséquent, il semble légitime de poser la question de la responsabilité de l'enseignant en ce qui concerne l'apprentissage et la socialisation des élèves. Si l'école, en tant qu'institution, ne peut pas éviter de poser cette question, il va sans dire que, tôt ou tard, cette interrogation, les enseignants se la posent eux-mêmes.

L'enseignement est un métier qui exige une grande flexibilité, une pratique exercée dans l'incertitude, où cohabitent diverses dimensions des rapports humains (Perrenoud, 1996). Il ne peut en effet se résumer à une tâche purement cognitive car les variables affectives, relationnelles, stratégiques, éthiques, et autres, le traversent (Tardif, 1993). Or, l'enseignement, ces dernières années, s'est considérablement complexifié notamment en raison de l'alourdissement des tâches des enseignants et de la diversification des clientèles scolaires (Robert \& Tondreau, 1997). Cette situation place l'enseignant devant des circonstances inédites auxquelles sa formation universitaire ne l'avait souvent pas préparé. Et, comme l'a démontré Schütz (1987), notre capacité à faire face aux événements est fortement liée au «stock de connaissances » que nous possédons, lequel s'appuie sur nos expériences antérieures. Dans ce contexte, l'interrogation sur l'effet enseignant acquiert une nouvelle pertinence et la question de la responsabilité du praticien quant aux 
apprentissages et à la socialisation des élèves se pose d'une manière inédite. Cette conjoncture est propice à l'émergence chez les enseignants du sentiment d'être débordé, de n'être pas en mesure de suffire à la tâche, de ne plus pouvoir produire l'effet escompté, bref, de ressentir un sentiment d'incompétence pédagogique.

On a traditionnellement traité l'incompétence professionnelle sous l'angle de la gestion scolaire (Bridges, 1993; Seyfarth, 1996). Selon cette vision, ce sont les fautes professionnelles graves - conduisant potentiellement au renvoi - telles l'incapacité de maintenir le contrôle de la classe ou de traiter les élèves de manière appropriée, l'incapacité à transmettre efficacement la matière, le refus de suivre le programme scolaire, l'abus envers les élèves ou le manque excessif de ponctualité, qui sont analysées. Ces recherches tentent ainsi de dégager un portrait des cas d'incompétence professionnelle afin de déterminer les meilleures mesures à prendre envers les enseignants impliqués. Or, outre le fait que ces recherches n'abordent pas la question du sentiment vécu par ces enseignants, les problèmes soulevés, selon Bridges (1993), ne concerneraient que 5\% du corps professoral. C'est dire que les autres (les 95\%) peuvent être jugés compétents. Cela n'implique toutefois pas que, dans la trame des micro-événements de la salle de classe et de l'école, ceux-ci se sentent toujours à la hauteur de ce qu'on attend d'eux et surtout, de ce qu'ils attendent d'eux-mêmes.

On sait que le sentiment de compétence apparaît comme un élément capital dans l'efficacité de l'enseignant. La psychologie cognitive a en effet montré que la perception de la contrôlabilité de la tâche est une dimension essentielle de la motivation (Tardif, 1992) et cette dernière s'avère une variable incontournable dans la réalisation adéquate d'un travail. On peut donc postuler a contrario que le sentiment d'incompétence est associé au sentiment de ne pas contrôler la tâche à accomplir et qu'il nuira à la motivation au travail. Les premières années du métier étant celles de l'insertion professionnelle et du nécessaire ajustement qu'elles impliquent, les enseignants en début de carrière seront de toute évidence les plus susceptibles à ressentir un tel sentiment d'incompétence. Par exemple, Grossman et Gudmundsdottir (1987) ont montré que l'acquisition de l'expérience en enseignement permet de raffiner et de rendre plus explicites les modèles de l'enseignement d'une matière. Ainsi, les enseignants expérimentés sont plus à même de résoudre les problèmes en classe notamment en raison de leur plus grande capacité à cerner les préconceptions et les stratégies des élèves.

Mais, comment circonscrire le concept d'incompétence pédagogique? Si la définition du concept de compétence pose problème en enseignement (Rey, 1996), il en va bien sûr de même pour son inverse: l'incompétence. 
Toutefois, afin de baliser le terrain il est possible ici de se donner quelques repères. D'abord, on définira l'incompétence pédagogique non pas comme une incapacité physique ou mentale, une faute criminelle (abus, alcoolisme, etc.) ou une faute déontologique au sens de la Loi de l'Instruction publique du Québec (L.R.Q. chapitre 1-13.3) mais en fonction d'une absence ou d'une faiblesse dans le contrôle de la tâche à accomplir (Martineau, Gauthier, \& Desbiens, 2000). Ensuite, cette absence ou cette faiblesse à contrôler une tâche pédagogique sera déterminée non pas a priori en fonction d'une représentation normative de la pratique enseignante mais à partir de l'interprétation que les enseignants font eux-mêmes. L'incompétence pédagogique est ici définie comme étant une absence ou une faiblesse dans le contrôle ou l'exécution de la tâche professionnelle, telle que perçue par le nouvel enseignant lui-même. Par le fait même, le concept de sentiment d'incompétence pédagogique renvoie donc au vécu cognitif et émotionnel lié à l'évaluation de la contrôlabilité de la tâche tel que mis en discours par les enseignants interviewés.

\section{Méthodologie}

Dans les deux recherches exploratoires présentées ici, nous avons eu recours à une approche qualitative reposant sur des entrevues de type semi-directif (Jones, 2000; Selltiz, Wrightsman, \& Cook, 1977). Ces entrevues abordaient les thèmes suivants. Pour les nouveaux enseignants: évaluation de la formation universitaire reçue, expériences d'insertion professionnelle, difficultés rencontrées en enseignement, stratégies pour les surmonter. Pour les directeurs d'écoles: processus d'accueil des nouveaux, problèmes les plus fréquemment rencontrés par les débutants, mesures de soutien offertes, attentes de compétences.

Dans un premier temps, à l'automne 1999, treize enseignants (5 hommes et 8 femmes) occupant un poste à temps plein dans une école secondaire de la grande région de Trois-Rivières, ont été interviewés.

Les répondants, dont l'âge varie entre 24 et 43 ans, avaient cinq années ou moins d'expérience et enseignaient diverses matières (langues, sciences pysiques et humaines, informatique et éducation physique) à tous les degrés du secondaire. Les rencontres ont duré environ $1 \mathrm{~h} 10$.

Dans un deuxième temps, en janvier et février 2001, nous avons interviewé six membres de directions d'écoles. Nos sujets se répartissaient à part égale entre les deux sexes ( 3 hommes, 3 femmes). Les rencontres, plus brèves qu'avec les enseignants novices, ont duré en moyenne 30 minutes. Pour l'ensemble des données, le processus d'analyse de contenu des entrevues s'est 
fait de la manière suivante. Nous avons d'abord procédé à une transcription intégrale des 19 entrevues. Cette procédure fut suivie d'une lecture flottante permettant de repérer les éléments les plus saillants. À une seconde lecture fut réalisée une thématisation plus systématique. Enfin les deux chercheurs ont procédé à la validation de l'analyse sur la base d'un accord inter-juge avoisinant les $90 \%$ pour $20 \%$ du corpus total des entrevues. Il n'a toutefois pas été possible de procéder à une validation écologique des analyses auprès des sujets rencontrés.

\section{Résultats}

Cette section fait état des résultats obtenus. Dans un premier temps nous présentons ceux concernant les enseignants. Puis, dans un deuxième temps, suivent les résultats des entrevues réalisées auprès des directions d'école.

\section{Les enseignants}

Premièrement, le sentiment d'incompétence pédagogique peut se ressentir tout autant dans les tâches liées au travail en classe avec les élèves que dans celles s'effectuant en dehors de cette enceinte protégée (sortie avec son groupe, travail avec les collègues, etc.). Mais, les dimensions relevant de la pratique en classe en présence du groupe d'élèves sont nettement dominantes confirmant en cela se que soutiennent Tardif et Lessard (1999) quant à la centralité du rapport face à face avec les élèves dans la définition du travail par les enseignants. Deuxièmement, lorsqu'il survient en classe, le sentiment d'incompétence peut être associé à la gestion de la matière (dimensions didactiques) ou à la gestion du groupe d'élèves (selon un découpage de la tâche enseignante devenu classique). On note cependant - et cela va dans le sens des recherches sur l'insertion professionnelle - une légère prépondérance des questions liées à la gestion de la classe sauf dans le cas où le sentiment d'incompétence pédagogique prend son origine dans le fait d'enseigner une matière qu' on ne maîtrise pas (par exemple, être formé en mathématiques et biologie et enseigner l'écologie). Troisièmement, et de la même manière, ce sont tout autant des activités pré-actives (préparation des cours), interactives (prestations en classe) ou post-actives (évaluation de son action ou correction des travaux par exemple) (Gauthier, Desbiens, \& Martineau, 1999) qui peuvent être la source de ce type de sentiment: difficultés à construire des outils pédagogiques ou des activités d'apprentissage, sentiment ou impression que l'on « ennuie » le groupe, dilemmes portant sur les modalités d'évaluation, etc. Quatrièmement, 
l'incompétence pédagogique, on l'attribue parfois à soi - manque d'expérience par exemple - ou à une cause extérieure - une formation initiale qui ne prépare pas adéquatement, l'impossibilité de « gérer » la situation adéquatement compte tenu des ressources (matérielles ou humaines) disponibles, ou des élèves trop « problématiques ». Cinquièmement, le sentiment d'incompétence pédagogique ne donne pas toujours lieu à des stratégies pour le surmonter. L'attitude semble souvent être teintée d'un certain fatalisme: «ça va passer avec le temps »; « je ne peux rien y faire ». Toutefois, lorsque les enseignants enclenchent des actions concrètes pour résoudre la difficulté, leurs préférences sont, dans l'ordre: a) consulter un collègue plus expérimenté, b) mettre « les bouchées doubles » pour acquérir des connaissances sur une matière avec laquelle on est moins familier, c) entrer dans un processus d'auto-réflexion sur son action, d) consulter la direction de l'établissement. Il faut cependant constater que la recherche en sciences de l'éducation (à tout le moins ses résultats publiés sous forme d'ouvrages ou d'articles) n'est ressortie à aucun moment comme source de référence pour développer des stratégies de résolution de problèmes liés au travail. De la même manière les enseignants débutants n'ont pas recours à l'expertise des professeurs d'université qui les ont formés. Sixièmement, en tant que représentation et évaluation de soi (comme pédagogue) et de l'efficacité de son action face à une situation donnée, le sentiment d'incompétence pédagogique apparaît étroitement lié à une représentation normative du bon enseignant construite par les nouveaux enseignants. Les termes les plus souvent employés pour qualifier cette représentation sont: guide, éducateur, modèle, initiateur, aide. On constatera qu'il y a ici reprise d'une partie de la terminologie en vogue dans le cadre des réformes en cours dans plusieurs systèmes d'éducation dont celui du Québec (Martineau \& Gauthier, 2002). En ce sens, le sentiment d'incompétence pédagogique est également associé à la pression à la conformité qui vient du milieu de travail.

Dans une certaine mesure, le contenu des entrevues auprès des nouveaux enseignants nous porte à croire que la socialisation au travail apparaît comme étant tout à la fois une « initiation » (au sens anthropologique du terme) à la culture professionnelle et une « conversion » (au sens religieux) du sujet à une nouvelle représentation du monde et de soi. Les sujets interviewés ont vécu durant leurs premières années un processus complexe de transformation en profondeur de leur identité professionnelle. D'étudiants en formation des maîtres, ils sont «presque » devenus des enseignants au plein sens du terme. La complète reconnaissance par les pairs plus expérimentés ne semble pas en effet tout à fait acquise. Même si l'abandon de la probation depuis 1998 a contribué à clarifier le statut des débutants (Lévesque \& Gervais, 2000), les nouveaux enseignants ne se sentent pas totalement perçus comme des « enseignants 
accomplis ». Ils expriment donc à de multiple reprises leur besoin de reconnaissance de la part des enseignants chevronnés. Ils veulent être perçus comme des collègues à part entière. Ils répugnent ainsi à être traités de manière condescendante mais reconnaissent qu'ils sont encore en apprentissage. Pour revenir au sentiment d'incompétence pédagogique, disons que celui-ci ne semble pas avoir été très profond. Ainsi, les problèmes évoqués ne sont pas insurmontables et leur gravité n'ébranle pas la confiance en soi des enseignants. Par exemple, aucun sujet n'a remis en cause sa carrière. Leurs représentations, leurs attitudes, leurs croyances, leurs valeurs n'ont pas été modifiées de manière drastique par les événements « dérangeants » vécus en classe. D'une certaine manière on pourrait presque dire que le sentiment d'incompétence pédagogique relève en quelque sorte du processus «normal » d'apprentissage du métier.

À travers l'expression de leur sentiment d'incompétence pédagogique, les enseignants rencontrés expriment aussi leurs besoins en matière de soutien à l'insertion professionnelle. Ces besoins concernent avant tout les savoirs pédagogiques. Ainsi, ils souhaitent obtenir des conseils sur les meilleures stratégies pour maintenir la discipline en classe ou encore qu'on leur donne de « bons trucs » pour susciter la motivation à apprendre chez les élèves. De plus, ils souhaiteraient recevoir une formation pour mieux maîtriser l'évaluation formative et sommative des travaux des élèves. En définitive, il semble que le sentiment d'incompétence pédagogique soit alimenté, du moins en partie, par le peu de soutien à l'insertion professionnelle dispensé par les directeurs d'établissements. Dans un sens, l'organisation individualiste de l'enseignement perdure (Tardif \& Lessard, 1999) et l'insertion professionnelle se fait sous le sceau de « la débrouille ». Néanmoins, malgré la faible appréciation de la formation initiale, malgré le peu de soutien de la part des collègues et de la direction, malgré une population étudiante jugée de plus en plus « problématique » au regard des valeurs et des normes scolaires, les enseignants semblent considérer ne pas trop mal s'en tirer. Tout semble se passer comme s'ils intégraient très tôt une vision du métier où il est légitime de ne pas « être toujours à la hauteur ». Cette vision du métier leur permet peut-être de supporter les moments difficiles sans remise en question radicale (voire même sans aucune remise en question).

\section{Les directeurs d'établissement}

Les éléments qui suivent font état des points de convergence du discours des directions quant aux compétences attendues envers les enseignants novices. Nous avons regroupé ces compétences en cinq grandes catégories. 
A. Les compétences en gestion de la classe. Les directions souhaitent que les nouveaux enseignants maîtrisent les compétences par rapport à la gestion de classe afin d'intervenir adéquatement en matière de la discipline.

B. Les compétences en gestion de la matière. On s'attend à ce qu'ils puissent préparer, planifier et transmettre adéquatement la matière qu'ils enseignent. Ainsi, les directions exigent des nouveaux enseignants qu'ils fassent preuve d'une excellente maîtrise des contenus à enseigner. Par ailleurs, on souhaite qu'ils aient, dès leur embauche, des compétences pédagogiques actualisées, c'est-à-dire adaptées aux nouvelles réalités éducatives (réforme, nouveau curriculum, régime pédagogique, etc.). Les directions s'attendent aussi à ce que les nouveaux enseignants possèdent une bonne connaissance de l'usage des technologies informatiques afin de les utiliser dans leurs cours et y entrainer les élèves. Enfin on exige qu'ils soient familiers avec les outils pédagogiques et les techniques d'enseignement intégrées comme l'apprentissage coopératif, la pédagogie par projet, et autres.

C. Les compétences en relations interpersonnelles. Les directions s'attendent à ce que les enseignants nouvellement embauchés soient capables d'établir de bons contacts avec les élèves ainsi qu'avec leurs collègues. On exige aussi qu'ils soient capables de s'impliquer, de partager et de participer à la vie de l'école.

D. Les compétences au travail en équipe. Bien que les directeurs rencontrés n'aient pas été très explicites à cet égard quant aux modalités d'actualisation de cette compétence, ils ont tout de même clairement exprimé leur exigence en terme de capacité du nouvel enseignant à travailler en équipe professorale tout en développant un style personnel. 
E. Les compétences éthiques. Les enseignants débutants devraient être des gens disciplinés, par rapport à leur profession et surtout par rapport au code de vie de l'école. Ils doivent se distinguer des élèves par leurs comportements, c'est-à-dire qu'ils doivent être des modèles pour les élèves (une bonne tenue en classe, habillement correct, bonne diction, respect des règlements de l'école) afin de ne pas être confondus avec eux.

F. Le processus d'accueil des débutants. En ce qui concerne le processus d'accueil des nouveaux enseignants, disons que celui-ci est loin d'être formalisé ou planifié. Les propos recueillis auprès de toutes les directions d'école convergent sur les éléments suivants. Les novices ont droit à une période d'accueil et de rencontres avec la direction de l'école ou par un membre du personnel de la direction (connaissance mutuelle, échange sur le vécu de l'école, sur les activités, la culture organisationnelle de l'école). Ensuite, les nouveaux sont présentés à l'équipe enseignante. S'ajoute régulièrement à cela une visite de l'école durant laquelle on explique entre autres les règlements à respecter, le programme d'études, le fonctionnement de l'établissement, le projet éducatif. Enfin, dans certain cas, il y a parrainage ou jumelage des nouveaux avec des « anciens » selon le domaine et le niveau d'enseignement (durée entre six et douze mois). Le parrain a pour tâche d'initier le nouveau à la préparation des cours, au suivi des élèves, au travail à faire pendant et après l'enseignement. Dans l'ensemble, les directions d'écoles négligent la question de la mise en place de mesures de soutien formel.

G. Les « incompétences pédagogiques ». Quant aux incompétences pédagogiques relevées par les directions chez les nouveaux enseignants, les entrevues laissent entrevoir les éléments qui suivent. D'abord, les débutants éprouvent régulièrement une certaine incapacité à assurer la discipline en classe, c'est-à-dire, qu'ils ont de la difficulté à maîtriser un groupe d'élèves (parce que, aux 
dires des directions, ils se font « trop amis » avec les élèves et parce qu'ils ne sont pas souvent disciplinés euxmêmes). On déplore aussi leurs réticences à demander de l'aide quand ils sont confrontés à des problèmes d'ordre professionnel, réticences qui peuvent toutefois s'expliquer par la crainte d'être jugés incompétents ou incapables. De la même manière, on relève leurs difficultés à remplir adéquatement les tâches de planification et de préparation des cours. De plus, leurs connaissances pédagogiques seraient souvent inadéquates au regard des programmes scolaires. Enfin, les débutants dans la carrière enseignante présenteraient de grandes lacunes quant à la culture générale (celle-ci n'est toutefois jamais clairement définie ni caractérisée par les directions).

\section{Conclusion}

Rappelons d'abord que nous rendons compte ici de deux recherches exploratoires et qu'à cet égard nos conclusions ne peuvent qu'être très prudentes et provisoires. D'abord, on peut dire que les débutants semblent ne pas trop mal se débrouiller durant leurs premiers pas dans la carrière. On constate ainsi que le sentiment d'incompétence ressenti par les treize enseignants rencontrés a été peu profond. Il fut en réalité vécu en relation avec des événements ponctuels et non pas en rapport à des événements récurrents. Par ailleurs, les stratégies de remédiation, lorsqu'elles existent, peuvent être qualifiées d'endogamiques à savoir que l'enseignant recherche des solutions en lui-même ou à l'intérieur de l'école (auprès d'un collègue) et exclut ainsi les sources extérieures telles les écrits scientifiques ou ses anciens professeurs à l'université. Ce comportement confirme le peu d'autorité qu'exercent les chercheurs et les formateurs en sciences de l'éducation auprès des praticiens de l'enseignement. Toutefois, selon nous, ce qui interpelle le plus fortement le monde de l'éducation c'est l'attitude que nous qualifierions de fataliste face aux situations professionnelles où le débutant se sent incompétent. Les nouveaux enseignants semblent en effet avoir développé très tôt une représentation de la profession comme étant un «métier impossible » ce qui pourrait, dans une certaine mesure, inhiber leur désir de trouver des solutions et entretenir ainsi une certaine apathie. Par ailleurs, en ce qui concerne plus globalement le processus d'insertion professionnelle, on peut dire qu'il se vit sur le mode informel plutôt que formel. Les directions semblent en réalité offrir peu de 
soutien à cet effet. De la même manière, les collègues apparaissent globalement peu présents en matière d'aide. En somme, le sentiment d'incompétence pédagogique renvoie à la fois à des phénomènes de systèmes (des conditions d'entrée difficiles, les « mauvais groupes », les pires horaires, la précarité d'emploi, une culture de l'individualisme où c'est « chacun pour soi dans sa classe », l'absence de structures d'insertion précises et formelles) et des logiques d'acteurs ( des attentes élevées mais implicites des directions, le fatalisme lié à une certaine représentation du travail, la recherche de solutions dans un spectre restreint de ressources).

En ce sens, les résultats de ces deux recherches exploratoires confirment les tendances observées dans des recherches récentes tant dans le champ de l'analyse du travail enseignant (Tardif \& Lessard, 1999) que dans celui de l'insertion professionnelle (Hétu, Lavoie, \& Baillauquès, 1999; Mukamurera, 1998).

\section{Références}

Bridges, E.M. (1993). The incompetent teacher. Managerial responses. Washington, D.C.: The Falmer Press.

Felouzis, G. (1997). L'efficacité des enseignants. Paris: PUF.

Gauthier, C., Desbiens, J.-F., Malo, A., Martineau, S., \& Simard, D. (1997). Pour une théorie de la pédagogie. Recherches contemporaines sur le savoir des enseignants. Sainte-Foy: Les Presses de l'Université Laval.

Gauthier, C., Desbiens, J.-F., \& Martineau, S. (1999). Mots de passe pour mieux enseigner. Sainte-Foy: Les Presses de l'Université Laval.

Grossman, P.L., \& Gudmundsdottir, S. (1987). Teachers and texts: An expert/ novice study in English (Knowledge Growth in a Profession Publication Series). Stanford, CA: Stanford University, School of Education.

Hétu, J.-C., Lavoie, M., \& Baillauquès, S. (eds.) (1999). Jeunes enseignants et insertion professionnelle. Un processus de socialisation? de professionnalisation? de transformation?. Bruxelles: De Boeck.

Huberman, A.M. (1989). La vie des enseignants. Évolution et bilan d'une profession. Neuchâtel/Paris: Delachaux \& Niestlé.

Jones, R.A. (2000). Méthodes de recherche en sciences humaines. Bruxelles: De Boeck.

Lévesque, M., \& Gervais, C. (2000). L'insertion professionnelle: une étape à réussir dans le processus de professionnalisation de l'enseignement. Éducation Canada, 40(1), 12-15. 
Martineau, S., \& Corriveau, G. (2000). Vers une meilleure compréhension du sentiment d'incompétence pédagogique chez les enseignants en insertion professionnelle au secondaire. Formation et Profession, 6(3), 5-8.

Martineau, S., \& Gauthier, C. (2002). Évolution des programmes scolaires au Québec: un aperçu historique pour mieux comprendre la réforme actuelle. In C. Gauthier \& D. Saint-Jacques (Eds.), La réforme des programmes scolaires au Québec (pp. 1-21). Québec: Les Presses de l'Université Laval.

Martineau, S., Gauthier, C., \& Desbiens, J.-F. (2000). Ce n'est pas toujours la faute à El Niño. À propos de l'incompétence en enseignement. In C. Lessard \& C. Gervais (Eds.), L'évaluation des nouveaux programmes de formation des maîtres: une compétence à développer (pp. 299-332). Montréal: Les Publications de la Faculté des sciences de l'éducation.

Mukamurera, J. (1998). Étude du processus d'insertion professionnelle de jeunes enseignants à partir du concept de trajectoire. Thèse de doctorat. Sainte-Foy: Université Laval.

Mukamurera, J. (1999, avril-mai). Les trajectoires d'insertion de jeunes profs au Québec. Vie Pédagogique, 111, 24-27.

Perrenoud, P. (1996). Enseigner: agir dans l'urgence, décider dans l'incertitude. Paris: ESF.

Raymond, D. (2001). Processus et programmes d'insertion professionnelle des enseignants du collégial. Pédagogie collégiale, 14(3), 22-27.

Rey, B. (1997). Les compétences transversales en question. Paris: ESF.

Robert, M. \& Tondreau, J. (1997). L'école québécoise. Débats, enjeux et pratiques sociales. Une analyse sociale de l'éducation pour la formation des maîtres. Montréal: CEC.

Schütz, A. (1987). Le chercheur et le quotidien. Paris: Méridiens Klincksieck.

Selltiz, C., Wrightsman, I.S., \& Cook, S.W. (1977). Les méthodes de recherche en sciences sociales. Montréal: HRW.

Seyfarth, J.T. (1996). Personnel management for effective schools ( $2^{\mathrm{e}}$ éd.). Boston: Allyn and Bacon.

Tardif, J. (1992). Pour un enseignement stratégique. L'apport de la psychologie cognitive. Montréal: Logiques.

Tardif, M. (1993). Savoirs et expérience chez les enseignants de métier. In H. Hensler (Ed.), La recherche en formation des maîtres. Détour ou passage obligé sur la voie de la professionnalisation? (p. 53-86). Sherbrooke: CRP.

Tardif, M., \& Lessard, C. (1999). Le travail enseignant au quotidien. Contribution à l'étude du travail dans les métiers et les professions 
d'interactions humaines. Sainte-Foy: Les presses de l'Université Laval.

Wideen, M., Mayer-Smith, J., \& Moon, B. (1998). A critical analysis of research on learning to teach: Making the case for an ecological perspective on inquiry. Review of educational research, 68(2), 130178.

Zeichner, K.M. \& Gore, J.M. (1990). Teacher socialization. In W.R. Houston, M. Huberman, \& J.K. Sikula (eds.), Handbook of research on teacher education (pp. 329-348). New York: MacMillan. 


\title{
The Use of Think-aloud Methods in Qualitative Research An Introduction to Think-aloud Methods
}

\author{
Elizabeth Charters \\ Seneca College of Applied Arts \& Technology
}

\begin{abstract}
Think-aloud is a research method in which participants speak aloud any words in their mind as they complete a task. A review of the literature has shown that think-aloud research methods have a sound theoretical basis and provide a valid source of data about participant thinking, especially during language based activities. However, a researcher needs to design a process which takes into account a number of concerns, by selecting a suitable task, a role for the researcher, a source of triangulation, and, most importantly, an appropriate method of interpretation. This paper argues that think-aloud research can be effectively interpreted through a qualitative lens. A qualitative approach also has implications for the choice of participant(s) and the treatment of the data. Participants should be treated as quasi-researchers, and their efforts rewarded with reciprocity.
\end{abstract}

Educators today stress our students' need to develop their ability to think and solve problems. Many hope to promote this thinking by using constructivist or problem-based lessons in the classroom. But researchers are only beginning to map out the actual mechanics of human thought processes. How, then, may teacher-researchers find out if our lessons truly do develop student thinking? Off and on, over the past century, psychologists and educational researchers have attempted to answer these questions by using a method called think-aloud to try to see into the minds of individuals. Participants are asked to voice the words in their minds as they solve a wide variety of problems, from mathematical equations to visual puzzles to reading comprehension. Individual researchers and theorists have debated the effectiveness of think-aloud techniques to illuminate thought processes in their particular area of research or pedagogy. As yet, however, there have been few discussions of the application of think-aloud techniques to the qualitative realm of research.

Elizabeth Charters is a professor of General Education at the Seneca College of Applied Arts and Technology in Toronto. Her work promotes literacy, often among adults studying while also learning English as a second language. 
I am a teacher-researcher who has used think-aloud techniques to research the thought processes involved when students combine sentences, an activity believed to promote writing skills (Charters, 2003). In my study, I used a combination of interview and think-aloud reports to explore the processes used by five participants, mostly adult ESL students, to solve several sentence combining problems. The results were interpreted through individual narrative and thick description. I found this approach effective. It not only provided a detailed picture of my participants' thought processes, but also helped to highlight individual differences in response.

In this paper, I will outline the roots of the think-aloud technique in cognitive and psycholinguistic theory and discuss its strengths and weaknesses as a research tool, based on both review of the literature and my own experience. From these findings, I can recommend an effective set of methods for think-aloud research which may avoid some of the limitations encountered by researchers in the past.

\section{The Theory of Think-Aloud Research}

Although think-aloud techniques in their current form have their roots in cognitive psychology, to understand the relationship of thought and words it is helpful to go back to Vygotsky's (1962) Thought and Language and its concept of "inner speech." His theory was that the "inner speech" of verbalized adult thought processes evolves from the "egocentric speech" of toddler monologues, also a form of "thinking aloud" with the goal of solving problems. Vygotsky described inner speech as "almost inaccessible to experiments" except through its earlier manifestation as egocentric speech (p. 131-132), but it is likely that the words adult participants in think-aloud studies utter are closely related to inner speech, especially considering their characteristics. Like egocentric speech, "think-aloud protocols" are "elliptical" in that they are usually not expressed in complete, reasoned sentences. Vygotsky noted that "sentences" in egocentric and inner speech are dominated by predicates, since the subject of the "talk" is usually visible and evident to the "speaker," and they may be even more fragmented. Similarly, anyone trying to understand another person's thought processes from think-aloud transcripts will find them more difficult to understand than normal speech or writing. This is a natural reflection of the purpose of inner speech, which is not meant to be communicative to anyone but the thinker.

Another important concept from Vygotsky's (1962) theory involves the relationship between abstract thought and inner speech. Although translation into language is necessary before thought can assume a form which others can 
understand, much of our thought is not "stored" verbally. As people develop and build our mental networks, our thoughts become increasingly abstract, and words are only part of their elaborate patterns of meaning. Vygotsky did not have the vocabulary of working and long-term memory, storage, and retrieval to clarify these concepts, but his ideas are important to an understanding of what think-aloud methods can and cannot reveal. Researchers need to be aware that even thinking aloud, which makes inner speech external, cannot reveal deeper thought processes in their true complexity because they have to be simplified into words before anyone, even the thinkers themselves, can really know them. This "bottleneck" between the breadth of abstract thought and the narrower, temporal emergence of verbal thought necessarily slows down thought processes. Researchers do not know for certain how much it also changes them before they are verbalized as "inner speech" which can be thought aloud (see also Pressley \& Afflerbach, 1995).

A speaker often takes several minutes to disclose one thought. In his mind the whole thought is present at once, but in speech it has to be developed successively.... Precisely because thought does not have its automatic counterpart in words, the transition from thought to words leads through meaning... and then through words. (Vygotsky, 1962, p. 150)

Vygotsky's (1962) understanding of the complex and dynamic relationship between thought and verbalized inner speech is useful to remember when studying the theoretical underpinnings of think-aloud methods in the simplified models of information processing theory, best explained in Ericsson and Simon's (1980) seminal study, Verbal Reports as Data.

Ericsson and Simon (1980) stressed the importance of the theoretical basis of think-aloud methods and related "introspective" research techniques. Their theory is based on a distinction between working memory, in which concurrent reasoning takes place in verbal form, and long-term memory, where some of the ideas from working memory are eventually stored, not necessarily in words. The goal of think-aloud research is to give the researcher insight into the processes of working memory, but there are several difficulties of which researchers need to be aware. First of all, only "heeded" or noticed information goes into working memory. Also, since working memory has a limited capacity, this information is held there only briefly and can disappear as soon as new thought patterns supersede it. For this reason, only verbal reports which follow very rapidly after a thought process can be supposed to accurately reflect conscious thought, and researchers must focus on the participants' "immediate 
awareness," not delayed explanations for their actions (Cooper, 1999, Olson, Duffy \& Mack, 1984). In addition, there are many thought processes which are not verbalized in working memory, either because they are automatic (such as recognition of familiar words and images) or because their "intermediate" processing passes through so quickly that there is no time to verbalize it (Davis \& Bistodeau, 1993, Ericsson \& Simon, 1980, Sugirin, 1999). For this reason, researchers need to choose the research task very carefully.

Ideally, researchers should aim for thinking-aloud of processes which are naturally verbal (Ericsson \& Simon, 1980), perhaps corresponding to Vygotsky's "inner speech." Processes which are not verbal, such as those involving physical actions or visual images, may be distorted when they are translated into words to meet the demands of a think-aloud task. Ericsson and Simon refer to a visual-spatial puzzle-solving study in which the group asked for "overt verbalization" of their strategies was more successful in solving the problem than a control group. Unfortunately for the accuracy of think-aloud research, this implies that requests for indirect verbalization might change the way people think. Researchers who want to use think-aloud techniques to reflect natural thought processes have to design their methodologies with great care to avoid over-influencing their participants. For these reasons, there are a number of potential problems to consider when you use think-aloud methods for research.

\section{Thinking Aloud as a Research Tool}

Olson et al., (1984) stated that using think-aloud technique is one of the most effective ways to assess higher-level thinking processes (those which involve working memory) and that it could also be used to study individual differences in performing the same task. Ericsson and Simon (1980) conclude that even if their view of thought processes is necessarily incomplete, verbal reports such as those from think-aloud data are a "thoroughly reliable" source of information about thought processes (p. 247). Nonetheless, before designing a research plan which involves think-aloud methods, researchers need to decide on the

type and level of difficulty of the research task, the degree of prompting which is appropriate, the use of other data to support inferences from think-aloud protocols, and the method of analysis.

\section{Suitable Tasks for Think-Aloud Study}

A task for think-aloud study needs to be chosen with care, keeping the cognitive abilities of the participants in mind. Ericsson and Simon (1980) found that 
demanding tasks creating a "high cognitive load" interfere with verbalization, because other processes crowd verbal information out of working memory. On the other hand, a simple task may also be unsuitable as 'the closer readers' activities come to automaticity, the more problematic it may be for readers to describe these automatic or near-automatic happenings" (Pressley \& Afflerbach, 1995, p. 132). This is why Akyel and Kamisli (1996) recommend that thinkaloud tasks require "cognitively demanding language use" beyond mere word recognition level so that participants cannot rely on automaticity to perform the task (p. 15-16). For all these reasons, a language-based activity at an intermediate level of difficulty for the target group is probably an appropriate task for think-aloud research because it requires more than an automatic response but should not be cognitively overwhelming. A task which can be broken into shorter units so that it can be worked on one unit at a time is also recommended because it would prevent overload of working memory. "Environmental supports" in the form of written texts which can be easily referred to also free up space in working memory so that higher-level thinking may occur. To see the effect of varying tasks, it may also be helpful to do as I and some other researchers (Johnson, 1992) have done, and include activities at several, successively more challenging levels of difficulty. In general, tasks which employ verbal thoughts naturally should provide the most accurate thinkaloud responses.

\section{The Issue of Prompting}

Ideally, participants in a think-aloud study should not need any coaching but should enunciate their inner speech spontaneously. Unfortunately, without some demonstrations and practice, students may not report their thought processes frequently or thoroughly enough to meet the researcher's needs. Nonetheless, some research methods which tried to improve their data by suggesting explicit strategies for students to talk about (Cooper, 1999; Davis \& Bistodeau, 1993) or asking specific probing questions (Olson et al., 1984) ran the risk of "leading the witness" and so distorting thought processes more than necessary.

Furthermore, Ericsson and Simon (1980) found that repeated practice of a task might promote automaticity before thought processes could be reported.

Some suggested strategies to encourage effective think-aloud responses seem less intrusive than detailed practice or explicit modeling. Sugirin (1999) used a KEEP TALKING sign to remind participants to verbalize all thoughts without addressing them in speech which might interfere with those thoughts. Gibson (1997) suggested a pretask orientation session which briefly explains the rationale and form of think-aloud research to reduce "cold start effect" (p. 
58), but thought that researcher modeling might introduce bias into "think-aloud reporting." Nor should researchers prompt participants to use a targeted process. As Pressley and Afflerbach (1995) concluded, "researcher silence about how the [task] might be processed is more defensible than directions that prompt particular processes, especially when the goal is to learn about the processes people naturally use" (p. 132-133). After all, participant pauses and omissions may reveal interesting insights into individual differences in thought processes, while any shortfall in the think-aloud results may also be supplemented by other sources of data gathering. In order to ensure that thinkaloud reports as are complete as possible, it is necessary to have a "reliability check" to provide "triangulation" (Sugirin, 1999, p. 2).

\section{The Need for "Triangulation"}

Few researchers in the think-aloud literature relied on think-aloud transcripts as their only source of data gathering. As Ericsson and Simon (1980) stressed, think-aloud data from working memory will always be incomplete and exclude a number of thought processes which are not held in working memory long enough to be expressed verbally. Think-aloud utterances may also vary in quantity and quality. In response to these problems, the most widely used follow-up strategy is retrospective questioning. Although this involves difficult retrieval from long-term memory, and may be biased by researcher questioning, Nunan (1992) concluded that these problems are offset when combined with the concurrent data from working memory. When retrospective questioning is used only to illuminate and expand on think-aloud results, it may add depth of information about the participant's thought processes. Rankin (1988) also recommended a retrospective analysis, particularly for those participants who had difficulty with the think-aloud method, while Pressley and Afflerbach (1995) point out that participants' ability to describe their thought processes may provide helpful information on their metacognitive skills. Qi (1998) suggested that a follow-up interview may also allow the participants to "validate" the researchers' interpretation of their think-aloud utterances; this would be particularly important when some of those utterances may be in the participants' first language. Davis and Bistodeau (1993) used both a "recall protocol" focused on the content of the task (reading comprehension) and an "exit interview" to help interpret the think-aloud data. However, Gibson (1997) warned that it is better to let the participants recall the task as far as possible without using the audiotape as a prompt. He also noted that retrospective data are most reliable when the time lag between think-aloud recording and exit interview is very short. 
There are a number of other strategies for data collection suggested by the literature. Akyel and Kamisli (1996) supplemented their think-aloud data with a questionnaire. Some of the studies reviewed by Ericsson and Simon (1980) involved control groups which performed the same task without thinkaloud reporting. However, there are so many potential causes of variations in think-aloud response that a test group/control group dichotomy is of limited help. Although some researchers have used videotaping as a clue to participants' physical action during think-aloud activities, Sugirin (1999) preferred casual researcher observation because it was less intimidating to the participants. Cullum (1998) listed a number of nonverbal cues which a researcher may note quietly; these include pauses, smiles, misreadings, and periods of silence which may indicate overload of working memory. Fontana and Frey (2000) also pointed out the need for researchers to notice not only the participants' choice of verbal language and terminology, but also their nonverbal communication, including "pace of speech,....body movement....and variations in vocal tone and volume" (p. 660-661). Noting what is not said might add to understanding of the interview transcripts, and help teachers, for example, "to visualize what...students are not hearing in their classrooms" (Peshkin, 2001, p. 247).

With my own participants, I wished to keep their think-aloud behaviour as natural as possible, even if it meant that the degree of information varied among them. Based on these suggestions, I collected my data by audiotaping participants' think-aloud utterances while sitting next to, not across from, them to minimize intimidation (Nunan, 1992) and taking informal written notes on their behaviour and tone of voice, trying to relate these observations to their progress throughout the task. During the "exit interview," after the tape recorder was turned off, I was able to add to my notes translations of first language utterances and participants' explanations of ambiguous passages, pauses, and other nonverbal responses. With this raw material in hand, I could then address the most challenging stage of the think-aloud research process: interpretation.

\section{Interpretation of Think-Aloud Data}

Since it would interrupt the natural flow of "inner speech" to ask participants for explanations of their actions during the think-aloud activity, and explanations given retrospectively are unreliable because they might not reflect the actual content of working memory (Ericsson \& Simon, 1980), researchers must be prepared to make their own inferences as they interpret think-aloud data. Many participants' utterances are ambiguous; they may repeat a phrase 
using various intonations as they search for its meaning, but they do not articulate this speculation. Other theorists also pointed out the need for researchers to make inferences (Davis \& Bistodeau, 1993). Although Rankin (1988) warned that any reconstruction of participant remarks should be "literal" and related closely to context, he admitted that some responses may represent more than one thought process and need to be interpreted as such. Olson et al., (1984) described their "impressions" of common participant responses (p. 265), which also involved inferencing. They referred to this as the "qualitative" part of their data.

In general, though many researchers used inference in describing and classifying their data, only one of those whom I examined used a completely qualitative approach (Cullum, 1998). Pressley and Afflerbach (1995) in their comprehensive study of think-aloud research into reading, also found that "various types of quantitative analyses were employed in the majority of studies" (p. 17). Is this widespread preference for quantitative research an indication that think-aloud data are most suitably analyzed this way?

Ericsson and Simon (1980) gave think-aloud research respectability among social scientists by arguing that researcher inferences about the meaning of think-aloud utterances are as objective as behaviourist inferences about the purpose of visible actions and can be quantified with equal validity. But, in the end, how objective can purely quantitative analyses be? Johnson's (1992) process-oriented study of ESL students combining sentences, a similar study to my own, may serve as a good illustration of some limitations to quantitative analysis of think-aloud data.

Like the other researchers, Johnson (1992) used a small number of participants (9), presumably because think-aloud procedures are so expensive and time consuming (see also Pressley \& Afflerbach, 1995). There was no exit interview, and the researcher disregarded pauses, "false starts," and other observable behaviours (p. 65). When the tapes were transcribed, participant utterances were divided into "communication units" equivalent to grammatical sentences: "a main clause and all the subordinate clauses attached to it" (p. 65), which correspond to the psycholinguistic concept of the "T unit" or "minimal terminable unit" of meaning (Cooper, 1999, p. 242). These units were then tabulated under one of 10 possible "cognitive strategies" and statistically analyzed to find which strategies were most frequently used. The results are plausible and useful, but, as many other quantitative think-aloud researchers also admitted, "limited because of the small sample size" (Johnson, 1992, p. 71). There are other problems with this method. Given that inner speech is "elliptical" or telegraphic, forcing students to produce complete sentences or artificially joining fragmented utterances into grammatically complete 
"communication units" may lead to misrepresentation of thought processes. Also, assigning each "communication unit" to one cognitive strategy oversimplifies the process; in reality, one utterance may reflect a more complex combination of strategies (Rankin, 1988). Finally, a research hypothesis which looks only for evidence of thought processes common to all participants disregards the existence of different thinking styles (see, for example, Merriam \& Caffarella, 1999), in addition to different learning styles and intelligences. If only one participant uses a specific strategy to solve a problem, are his data less relevant than those of the others?

Think-aloud studies that employed quantitative methods have sought to generalize the experiences of certain populations of students. Researchers, such as Johnson (1992), have sought to generalize their subjects' experience by codifying their utterances and identifying numerical patterns amongst them. It may be equally valuable, however, to avoid such generalization, especially since differences among participant responses have been underplayed in previous, mostly quantitative, research (Pressley \& Afflerbach, 1995). For all these reasons, the depth, variety, and complexity of thought processes may be equally effectively interpreted using a qualitative approach. Qualitative researchers, who prefer to describe, rather than codify, may allow a clearer picture of the variability of individual experience to emerge. However, there are a number of issues to bear in mind before qualitative researchers can present a fair and accurate interpretation of think-aloud data, including the interpretive angle, the nature of the participants, and the treatment of their data.

\section{Qualitative Methods Appropriate for Interpretation of Think-Aloud Research}

\section{Think-Aloud Research through Case Study}

Think-aloud researchers, as well as asking the narrative question "what happened," are grappling with the expository question "how does it (the target process) work?" They need a method that is flexible enough to accommodate such a blending of interpretive angles. Rankin (1988), although his own analysis was quantitative, suggested treating each think-aloud participant as a "small" "tightly focused" case study (p. 122). Such an approach may be appropriate for qualitative think-aloud researchers, for a number of reasons.

A pragmatic justification emphasizes the applied nature of case study research. As a method it can be advocated on grounds that it is more useful, more appropriate, more 
workable than other research designs for a given situation. Knowledge produced by case study would then be judged on the extent to which it is understandable and applicable... a pragmatic conception of truth undergirds this approach.

(Merriam, 1988, p. 20)

Many theorists have demonstrated that effective case study may be used to interpret results from a naturalistic or holistic point of view (Stake, 1994). According to these theorists, case studies can be non-experimental "when description and explanation (rather than prediction based on cause and effect) are sought" and when "it is impossible to identify all the important variables ahead of time" (Merriam, 1988, p. 7). Case studies also can deal with a "full variety of evidence-documents, artifacts, interviews and observations" (Yin, 1984, p. 20), and employ "any and all methods of gathering data, from testing to interviewing" (Merriam, 1988, p. 9). Most important, descriptive case study also allows the researcher to "illustrate the complexities of a situation,... show the influence of personalities, [and]... include vivid material - quotations, interviews... and so on" (Merriam, 1988, p. 14). Such an approach may give researchers greater flexibility to describe results naturally, without having to tailor them to a preconceived hypothesis, and to draw inferences from whichever source, think-aloud transcripts, exit interview or informal observation, is most revealing.

This is what Cullum (1998) did in her descriptive, in-depth study of her daughter's experiences using think-aloud techniques to encourage her success and enjoyment in reading. A case study approach enabled Cullum to describe her subject, Annie, in great detail, making her family background, personality, and interests clear to the reader and providing a nuanced narrative of the changes Annie experienced through the course of the think-aloud experiment. This experiment did not pretend to be generalizable, for if a different child were exposed to the same experimental process, it is highly unlikely that the results would be the same. This does not negate the validity of Cullum's study and its findings that Annie did in fact benefit from think-aloud in a number of significant ways.

\section{Choice of Participants}

Although the typical case study, like Cullum's (1998), involves in-depth and possibly lengthy observation of one participant or situation, what Stake (1994) designates "collective case study" better fits a typical think-aloud study which explores the experiences of a small number of participants. Using more than 
one participant enables researchers to observe a wider range of responses, but, as Stake asserts, the choice of the cases need not necessarily be deliberate.

"They may be similar or dissimilar, redundancy and variety each having voice. They are chosen because it is believed that understanding them will lead to better understanding ... about a still larger collection of cases" (p. 237).

Qualitative research is most effective when the researcher "develops categories from informants rather than specifying them in advance of the research" (Creswell, 1998, p. 77). This is because the naturalist understands that every research subject is unique, and thus "the concept of 'population' is itself suspect” (Lincoln \& Guba, 1985, p. 298). Qualitative researchers believe that anyone they work with will have something worthwhile to reveal and that individual responses, however they could be categorized, are ultimately unique.

In my own study, I invited participation from any of my former students who expressed an interest. Those who volunteered could have been categorized according to sex, age, and background, but I did not focus on such superficial differences. Even if all my participants had turned out to be, say, female Chinese university graduates in their early 30s, there still might have been great variability in their experience. How could I have determined whether any differences were due to their nationality, language background, gender, or some completely different factor, such as learning style? It was more important to have participants who were interested in the study and willing to help me explore their writing processes as quasi-researchers than participants who represented a pre-selected range of backgrounds.

\section{Qualitative Interviewing and Transcription}

The qualitative model for interview-based research maintains that "questions...to which interviewing and participant observation may lead can only be toughly determined at that outset" (Howe \& Moses, 1999, p. 40) and that "unstructured interviewing can provide a greater breadth of data than the other types" (Fontana \& Frey, 2000, p. 652). Although the think-aloud data itself are centred on a structured task, the gathering of peripheral information about the participants may be more open-ended. In order to get some sense of the complexities of my own participants' situations, I began by encouraging them to tell me about their backgrounds and interests in a preliminary interview, using prompting questions only when they seemed unsure of what to say. In the post-interview, I invited participants to discuss their feelings about the thinkaloud experience, and reflect further on their thought processes. At all times I treated each participant as an individual, fellow adult, and, to some extent, fellow researcher, aiming for "the establishment of a human-to-human relation 
with the respondent and the desire to understand rather than to explain" (Fontana \& Frey, 2000, p. 654). My study benefited from such an approach because open-ended discussion allowed some fascinating details to emerge that were not addressed by the planned questions. I also gained insights on what had been said and unsaid as I struggled to prepare an accurate and detailed transcription.

Transcription is a stage where qualitative researchers attempt to show respect for both their participants and their future readers, bearing in mind that "transcription itself is an interpretive process" (Kvale, 1996, p. 160). Qualitative transcribers should aim to describe the think-aloud activity in detail, including non-verbal observations such as tone of voice, while acknowledging that their own interpretation of the experience affects the way it will be written down. Kvale further pointed out that "analysis of the transcribed interviews is a continuation of the conversation which started in the interview situation" (p. 280), and it makes sense for the second parties in the conversation, the interviewers, to have their voices included at this stage too. In my own case, I attempted to interpret the transcripts holistically, joining together the participants' words and additional comments with my own observations based on the field notes and on my theoretical understanding. Unlike Johnson (1992), I made few explicit comparisons, interpreting each participant's data largely independently of the others' and describing participants' think-aloud utterances and nonverbal response as they appeared, without trying to classify them into hypothetical categories. In this way I, as researcher, was consciously constructing meaning from a variety of sources, but I kept in mind that my own was just one possible interpretation since "qualitative research leads to as many interpretations as there are researchers" (Kvale, 1996, p. 279).

In order that researchers' voices should not drown out the participants', it is standard practice to meet with participants to let them approve interview transcripts. According to Lincoln and Guba (1985), this sort of "member checking" plays a critical part in maintaining the trustworthiness of qualitative or naturalistic research, for several reasons. It ensures that the interpretation accords with what the participant intended by his words, it allows factual errors to be corrected, and it provides an opportunity for the participant to add further thoughts and comments (p. 314). In my own study, as soon as possible after the transcriptions were completed, my participants were invited to review and comment on the summaries I had made of their think-aloud experience, so that I could take into account their own perceptions of their thinking (Firestone, 1987). This also provided an opportunity for further reflection on the whole process. 


\section{The Issue of Reciprocity}

Thus participants in a qualitative think-aloud study provide information in a number of different ways. They may narrate their relevant background experiences, complete activities while thinking aloud, and reflect on their thoughts immediately after. Later they may meet with the researchers again to review the interpretation of their earlier words and actions. In the end, then, qualitative researchers are asking a great deal more of their participants than merely their informed consent. They require "active assistance..., including a level of research cooperation which frequently amounts to colleagueship" (Wax, 1982, p. 44). This raises the ethical question about parity: Are the participants' potential gains from research studies in line with the demands on their time and intelligence? If participation is truly voluntary, they should be. From feedback during my own study, I can attest that at least some of my participants appreciated an opportunity to express their feelings about their difficulties and successes both in specific English courses and in language learning in general. Some found the audiotaping and transcribing process intellectually intriguing. Some also found that telling their story and seeing it written out in a coherent way helped them to look at their difficulties in context and provided greater self-understanding. These potential benefits may have provided some "reciprocity" for my participants' vital contribution to my study, and participants in other qualitative think-aloud studies may likewise feel rewarded (Dalton, Lantaigne-Richard, \& Quattrocchi, 2000, p. 159).

\section{Conclusion}

In general, the literature of think-aloud research shows its strong theoretical foundation and confirms its value as a way of exploring individuals' thought processes. Many studies also provide helpful ideas on the design and implementation of research studies, including selecting a task which offers an effective level of cognitive challenge, allowing an authentic outlet for inner speech, and providing "triangulation" through informal observation and an indepth exit interview. However, the literature's emphasis on quantitative analysis may be too restricting. As previous researchers have found, looking for consistent mathematical patterns among statistically insignificant numbers of participants is limited in its usefulness and overlooks the possibility of individual differences. I recommend that future researchers consider designing and interpreting think-aloud research through a qualitative rather than quantitative lens. 
The Use of Think-aloud Methods in Qualitative Research

\section{References}

Akyel, A. \& Kamisli, S. (1996). Composing in first and second languages: Possible effects of EFL writing instruction. Paper presented at the Balkan Conference on English Language Teaching of the International Association of Teachers of English as a Foreign Language, Istanbul, Turkey. (ERIC Document Reproduction Service No. ED 401 719)

Charters, E. (2003). Sentence combining and thinking: A study of adult ESL learners. Unpublished thesis. Brock University, St. Catharines, ON.

Cooper, T. C. (1999). Processing of idioms by L2 learners of English. TESOL Quarterly, 33(2), 233-262.

Creswell, J. W. (1998) Philosophical and theoretical frameworks. In J. S. Creswell, (Ed.), Qualitative inquiry and research design: Choosing among five traditions (pp. 73-91). Thousand Oaks, CA: Sage.

Cullum, L. (1998, January). Encouraging the reluctant reader: Using a think-aloud protocol to discover strategies for reading success. Report for Department of English, Indiana University of Pennsylvania. (ERIC Document Reproduction Service No. ED 420 837)

Dalton, J., Lantaigne-Richard, M., \& Quattrocchi, M. (2000). Researching teaching through collaborative inquiry with students. In A.L. Cole \& J.G. Knowles (Eds.), Researching teaching: Exploring teacher development through reflexive inquiry (pp. 151-165). Boston: Allyn \& Bacon.

Davis, J. N., \& Bistodeau, L. (1993). How do L1 and L2 reading differ? Evidence from think-aloud protocols. Modern Language Journal, 77(4), 459-472.

Ericsson, K. A., \& Simon, H. A. (1980). Verbal reports as data. Psychological Review, 87(3), 215-251.

Firestone, W. A. (1987). Meaning in method: The rhetoric of quantitative and qualitative research. Educational Researcher, 16(7), 16-21.

Fontana, A., \& Frey, J. H. (2000). The interview: From structured questions to negotiated text. In N. K. Denzin \& Y. S. Lincoln (Eds.), The handbook of qualitative research ( $2^{\text {nd }}$ ed., pp. 645-672). Thousand Oaks, CA: Sage.

Gibson, B. (1997). Taking the test: Using verbal report data in looking at the processing of cloze tasks. Edinburgh Working Papers In Applied Linguistics, 8, 54-62. (ERIC Document Reproduction Service No. ED $409713)$

Howe, K. R., \& Moses, M. S. (1999). Ethics in educational research. Review of Research in Education, 24, 21-59.

Johnson, K. E. (1992). Cognitive strategies and second language writers: A reevaluation of sentence combining. Journal of Second Language Writing, 1(1), 61-75. 
Kvale, S. (1996). The 1,000 page question. Qualitative Inquiry, 2(3), 275-284. Lincoln, Y. W., \& Guba, E. G. (1985). Establishing trustworthiness. In Y.S. Lincoln \& E.G. Guba (Eds.), Naturalistic inquiry (pp. 289-332). Newbury Park, CA: Safe.

Merriam, S. B. (1988). The case study approach to research problems. In S.B. Merriam (Ed.), Case study research in education: A qualitative approach (pp. 5-21). San Francisco: Jossey Bass.

Merriam, S. B., \& Caffarella, R. S. (1999). Learning in adulthood: A comprehensive guide. ( $2^{\text {nd }}$ ed.). San Francisco: Jossey-Bass.

Nunan, D. (1992). Research methods in language learning. Cambridge University Press.

Olson, G. J., Duffy, S.A., \& Mack, R. L. (1984). Thinking-out-loud as a method for studying real time comprehension processes. In D.E. Kieras \& M.A. Just (Eds.), New methods in reading comprehension research (pp. 253-286). Hillsdale, NJ: Erlbaum.

Peshkin, A. (2001). Angles of vision: Enhancing perception in qualitative research. Qualitative Inquiry, 7(2), 238-253.

Pressley, M. \& Afflerbach, P. (1995). Verbal protocols of reading: The nature of constructively responsive reading. Hillsdale, NJ: Erlbaum.

Qi, D. S. (1998). An inquiry into language-switching in second language composing processes. Canadian Modern Language Review, 54(3), 413-435.

Rankin, J. M. (1988). Designing thinking aloud strategies in ESL reading. Reading in a Foreign Language. 4(2), 119-132.

Stake, R. E. (1994). Case studies. In N. Denzin \& Y. Lincoln (Eds.), Handbook of qualitative research (pp. 236-247). Thousand Oaks: Sage Publications.

Sugirin. (1999, February). Exploring the comprehension strategies of EFL readers: A multi-method study. Paper presented at an International Workshop on Written Language Processing at the University of New South Wales, Sydney, Dec. 9, 1998. (ERIC Document Reproduction Service No. ED 428 548)

Vygotsky, L. S. (1962). Thought and language. (E. Hanfmann \& G. Vaker Eds., Trans.). Cambridge, MA: MIT Press.

Wax, M. (1982). Research reciprocity rather than informed consent in fieldwork. In J. Sieber (Ed.), The ethics of social research: Fieldwork, regulation, and publication (pp. 33-48). New York: Springer-Verlag.

Yin, R. K. (1984). Case study research: Design and methods. Beverley Hills, CA: Sage Publications. 


\section{BOOK REVIEWS}

The Graduate Grind: A Critical Look at Graduate Education

Patricia Hinchey \& Isabel Kimmel. New York: Falmer Press, 2000.

Reviewed by Annabelle L. Grundy and Michelle K. McGinn, Brock University

Abandonment, abuse, anxiety, betrayal, bitterness, breaking point, burnout, collapse, danger, death, desperation, discouragement, divorce, exhaustion, frustration, grind, hardships, hazing, hurdles, ignorance, impossible dream, isolation, killing the spirit, leaving, loneliness, murder, neglect, peril, ridicule, ritual, self-protection, sexual harassment, shock, snobbery, strain, strangulation, stress, suffering, suicide, survival of the fittest, trauma, and violence.

As Hinchey and Kimmel (2000) argue, "The culture of graduate study is rife with metaphors reflecting doctoral study as a perilous - a downright dangerous-enterprise" (p. 1). We extracted the alphabetical list above from the first three pages of their book, The Graduate Grind. Many similar words and metaphors are introduced throughout the book. For us, the powerful words and metaphors provoked an emotional, almost visceral response. Even though our own past and present graduate experiences have been more positive than the stories presented in the book, we found the portrayals credible and, unfortunately, too real. Graduate education and the culture of graduate schools can be oppressive and disheartening. Building upon a solid review of published literature and extended interviews with current and former graduate students, Hinchey and Kimmel use the lens of critical theory to question present practices in graduate education and propose a model for "how things might be otherwise."

We feel that this book is a worthwhile read and we recommend it for students, faculty members, staff members, and university administrators as a means to raise awareness about institutional culture and the different kinds of power inherent in all levels of university education, most notably graduate education. For readers seeking work from a critical theory perspective, this book is an excellent example of careful scholarship. The authors present a clear description of the nature, purpose, and method of critical theory. As they explain, critical theory draws attention to power inequities and the ways that those inequities disadvantage the less powerful within a relationship. In graduate education, graduate students are obviously less powerful than faculty members or the institution itself. Hinchey and Kimmel proclaim that their goal 
is "to promote more equitable and just power arrangements within graduate education" (p. 20) by exposing and questioning the (often implicit) inner workings of power within graduate institutions. Through the book, the authors attempt to raise awareness about power inequities within graduate education and to seek transformation of the institutional cultures that contribute to the oppressiveness of these power inequities. The book provides a clear and readable example of critical theory scholarship that can serve as a good model for other would-be critical theorists. Given that the focus of this study is graduate education, graduate students will be able to relate particularly well to the model provided.

Hinchey and Kimmel quote Paulo Freire's definition, which states that oppression is "any situation in which 'A' objectively exploits 'B' or hinders his [or her] pursuit of self-affirmation as a responsible person" (cited on p. 21). Cases abound in graduate schools where students' intellectual labours are belittled or devalued. Instructor feedback on course assignments may involve a derogatory tone. The overemphasis on grades and ranking may diminish emphasis upon other human qualities. Students' contributions to class discussions may be overlooked or ignored. Limits may be placed upon the types of research that are sanctioned within a department or a discipline. Decisions about authorship for collaborative work may not always fully represent the students' contributions to the work. Students' ideas and written work may be used without acknowledgement or financial compensation. These incidents of oppression erode students' sense of self, undermine their confidence, and exacerbate their fears.

Oppression may be intentional. Some faculty members are fully aware of the oppression of graduate students because they themselves experienced this oppression when they were graduate students. For these individuals, there is a sense that "I lived with it, now it's your turn." For others, the oppression is unintentional. Hinchey and Kimmel make the important point that oppression need not be an intentional act. The institutional culture within universities rewards certain behaviours that lead to increased power and recognition for those who follow the status quo. This leads to many unintentional forms of oppression. Students are often caught in the middle as representatives of the institution strive toward their own goals. Institutional reputations are built upon the kinds of features that are portrayed in media (e.g., Maclean's annual ranking of universities). In order to attract students and government funding, the university administration needs to emphasize features that can be positively documented. Similarly, reward structures for faculty members emphasize research productivity over teaching, thereby influencing the amount of time and 
attention that faculty members can devote to responsibilities that do not lead to research publications.

Hinchey and Kimmel raise awareness about the oppressive nature of institutional and individual practices through excerpts from interviews and published documents about graduate experiences. They focus particular attention on the complexities of lived experience for students in relation to their positions within multiple cultures or groups. Students' experiences are shaped by their gender, sexual orientation, age, race, class background, abilities, research interests, regional positioning, and other individual differences. Hinchey and Kimmel provide detailed discussion about the experiences of women students, students of colour, older students, lesbian and gay students, and working class students. Their descriptions of the particular difficulties faced by students from one or more of these categories are thoughtful and informative. However, we were surprised that the authors made no mention of students with disabilities. In an institutional culture focused on ability and excellence, disability may be treated as an aberration that could be viewed as a drain on limited resources. Students with disabilities are particularly susceptible to oppression because of their disabilities, as well as the stigma attached to having disabilities. Hinchey and Kimmel's critical theory perspective would provide a useful lens to consider the oppression faced by students with disabilities. We would have liked to see some attention to the experiences of students with disabilities in the book.

Throughout the book, Hinchey and Kimmel incorporate quotations from students who have experienced oppression within graduate institutions. The anecdotes provide concrete and realistic examples that illustrate "the hidden workings of power" (p. 20). These stories are most powerfully drawn in the chapter entitled, Voices of the Oppressed. The students and former students described their experiences in extended narratives using their own voices and without the interference of explicit editorial comments. The chapter provides space for voices from students who felt particularly oppressed. The students in this section use powerful metaphors that echo the list that we used to begin this review. For example, these students described feeling like flies caught in spider webs, mere cogs in the whole scheme of things, token minorities, slaves of the department, or circus acrobats jumping through hoops. To some extent, we found this chapter the most challenging to read because of the extremely negative experiences documented and the limited options or outcomes available. However, we recognize that the most oppressed are the ones whose voices most deserve to be heard, and we applaud Hinchey and Kimmel for providing space for these students' voices. 
Hinchey and Kimmel's focus on raising awareness about oppressive behaviours is intended to lead to change or transformation. This change can come about in one of two ways. First, oppressed individuals who become aware of their oppression may be in better positions to react with the limited power that they hold within a situation. For graduate students, this might include decisions to walk away and refuse to engage in an oppressive situation. However, quitting is not the only solution. Other forms of resistance are available through self-advocacy or collaborative efforts. For example, graduate students could sign petitions or make representation to a departmental review committee. Hinchey and Kimmel also relate an example where a graduate student faced a very draining dissertation defense and needed to make revisions within a short time frame. A small group of other graduate students worked together to edit the dissertation on behalf of the emotionally distraught candidate. Second, oppressors who become aware of the oppressive nature of their behaviours, may strive to change those behaviours. For faculty members, this means making a commitment to use their power for the betterment of graduate students not their detriment. Such initiatives might include arguing on behalf of graduate students in departmental policy changes. On a more individual basis, this could also involve, for example, organizing classes to be more inclusive of all students and providing appropriate compensation and acknowledgement for students' contributions to collaborative work. However, as Hinchey and Kimmel argue, it will take more than individual efforts to effect real change.

Universities are medieval institutions that are highly resistant to change. Hinchey and Kimmel point readers to existing scholarship that questions whether change is likely given that these changes require powerful individuals to accede some of their power to others. However, they argue that this resistance to change does not mean that change is impossible. Raising awareness is an important first step toward effecting change and The Graduate Grind does an exceptional job at raising awareness of oppression within graduate education. Beyond raising awareness, the book also provides some suggestions for how things might be otherwise. As Hinchey and Kimmel argue, "If we are to make any progress at all, we must begin with trying to imagine how things might be different .... If we can't imagine an alternative reality, we certainly can't pursue one" (p. 136). In the final chapter, they ask what changes are needed and present possible starting points for reform. They discuss such practical concerns as funding, accountability, advising and mentoring, and expectations for programs and people. These practical concerns can provide immediate improvements in graduate experiences, but, as critical educators, Hinchey and Kimmel have concerns about wider philosophical issues of 
developing critical consciousness, realizing community, and nourishing the human spirit. These concerns can only be addressed through a reconceptualization of graduate education based upon "attending to the lived experience of everyone engaged in graduate education, and...valuing graduate education as a human enterprise rather than an institutional enterprise linked to income and prestige" (p. 151). While this lofty goal may seem unachievable in the near future, it is certainly one that is well worth pursuing and Hinchey and Kimmel provide some excellent starting points for transformation, most importantly they provide a vision for how things might be otherwise.

The Graduate Grind is a readable, yet not readable book. The writing is clear and powerful and the subject is engaging, yet it is discouraging and difficult to read the extremely negative cases. Reading the book involves some hard slogging through negative experiences before finally getting to the positive potential provided in the concluding chapter. This is not a light read, but it is an important read for all those who are involved in graduate education.

\section{Authors' Note}

The two authors shared responsibility for the production of this review. This work was supported in part by Standard Research Grant \# 410-2002-0630 from the Social Sciences and Humanities Research Council of Canada. We thank our colleagues Michael Manley-Casimir, Carmen Shields, and Nancy Fenton for their ongoing contributions to our collaborative efforts.

Technology in its Place: Successful Technology Infusion in Schools

J. F. Lebaron, and C. Collier, Eds. San Francisco: Jossey-Bass, 2001

\section{Reviewed by Dirk Windhorst, Redeemer University College}

A reader might interpret the title of this short book in one of two ways: A teacher skeptical of the benefits of technology may believe that this book will argue that computers and the Internet must be given a limited educational role and will show educators how this may be done successfully. After all, when you "put something in its place," you are reducing its influence in changing or disturbing the context in which it is embedded. Alternately, a technology enthusiast may not read such a connotation in the first part of the title; indeed, he or she may skip over it immediately to the second part of the title and look forward to reading a book that describes effective techniques for integrating 
technology with student learning. The latter interpretation of the title proves to be correct.

Twelve authors, including the editors, John F. LeBaron and Catherine Collier, have contributed ten chapters - eight of which provide snapshots of how technology is being successfully implemented in some North American schools, and two of which explore the European context. The European connection was cultivated by LeBaron (Professor of Education at the University of Massachusetts, Lowell) when he studied educational technology on a Fullbright scholarship at the University of Oulu in Finland. Collier is a technology specialist with the Shirley School District in Massachusetts and an adjunct professor of technology in education for Lesley University (Cambridge, Massachusetts).

Even though the 12 authors tackle a variety of issues from classroom implementation of computer-assisted inquiry (chapter one) to building corporate partnerships and public support for technology infusion (chapters eight and nine), they are united by the theoretical framework of constructivism: students construct knowledge as they interact with technology and each other. The teacher's role is to provide the scaffolding for student inquiry in a technology-rich environment. In chapter four ("Technology and Learning: Getting the Story Out"), Jarvela argues that technology is our best tool in motivating and helping students learn in a constructivist framework. In his chapter, "Curriculum Planning for TechnologyRich Instruction," LeBaron tries to distance himself from the behaviorist, endsmeans view of learning exemplified by Ralph W. Tyler (1949) and embraces constructivism. Yet, his six stages of curriculum planning bear a marked resemblance to Tyler's Rationale.

In chapter six, Pulkkinen and Ruotsalainen are similarly optimistic about how the constructivist model of learning can be advanced through on-line learning where "collaborative methods of study develop students" critical thinking and direct them toward the construction of their own knowledge though discussion..." (p. 74). However, when the authors evaluated an on-line course that included university students based in four European countries, a major problem surfaced: most of the students had difficulty with independent goal-setting and self-directed learning. It seems that not enough scaffolding had been provided by the course tutors to help these students make the transition from a traditional model of learning to a constructivist one.

School principals who aspire to provide instructional leadership in technology integration will find chapter seven helpful ("The Computers Are Here!'). Perry and Areglado clearly lay out an eight-step change process that principals can follow if they wish to have their teachers and students exploit the full educational value of computers.

Teachers who are looking for practical tips in using computers and the 
Internet with their own students at the elementary or secondary level will be disappointed in most of this book which is written for other stakeholders.

However, chapters one and five are the exceptions. In chapter one, Abilock shares her experiences providing leadership in curriculum at a school in California. She provides a model for using technology for higher-order research, thinking and communication and lists a number of web sites that teachers can browse.

Unfortunately, this reviewer found many of these sites to be unavailable. This was not the case with Collier's chapter: "Staff Development for Technology Integration in the Classroom." One web site in particular, WebQuests, is very intriguing: it gives hundreds of examples of teacher-designed web activities that span all grades and subject areas.

Collier underscores the importance of the teacher's role in assisting students in using computers wisely. Rather than making teachers redundant, information technology requires that teachers provide students with formal instruction in keyboarding, in structured note taking, in purposeful and productive searching, in evaluating information critically, in synthesizing divergent points of view, and in presenting key ideas (pp. 68-69). Computers are not necessary for these skills to be taught, but these skills are very necessary for anyone who seeks to use the Internet with intelligence. Notwithstanding Zimmerman's hope that technology will help us solve teacher shortages (p.108), the physical presence of teachers among small groups of students is vital if we want to make sure that students will be able to withstand the temptation of digital plagiarism.

Technology is never defined in this book. It is assumed that we know that "technology" refers to computers and the related software and hardware of networks. For those who study the impact of technology on all aspects of modern life - including education - this definition is too narrow. Computers and fiber optic cables are the artifacts of a technological spirit that has its origins in the seventeenth century with Francis Bacon's “interrogation of nature.” Grant (1986) defined technology as the co-penetration of knowing and making in which both activities are changed. The authors of Technology in Its Place intuitively understand that constructivism fits within the spirit of technology as Grant defined it. Our knowing has become a kind of making, and as we immerse ourselves with digitalized data in the confines of cyberspace, we find it harder to imagine that knowing could be understood in any other way.

\section{References}

Grant, G. (1986). Technology and justice. Toronto: Anansi.

Tyler, R. (1949). Basic principles of curriculum and instruction. Chicago: University of Chicago Press. 